\title{
ANONYMIZACE OSOBNÍCH ÚDAJU゚ V SOUDNÍCH ROZHODNUTÍCH
}

\author{
JOHN A. GEALFOW ${ }^{1}$, CHRISTIAN MAY ${ }^{2}$
}

\begin{abstract}
ABSTRAKT
Míra anonymizace osobních údajů obsažených $v$ rozsudcích tuzemských soudů je značně nejednotná. Př́stup jednotlivých soudů závisí na nejasných kritériích, často je patrné, že se soud jakožto povinný subjekt podle zákona o svobodném př́stupu $k$ informacím nad nimi ani nepozastavil. Pomocí analýzy základních principů jednotlivých druhů soudního ř́zení a principů, na kterých je založeno právo na informace, ochrana osobních údajů a také filozofie ochrany základních práv, lze ovšem dojít k závěru o tom, jaká míra anonymizace se má $v$ konkrétním př́padě zvolit. Tento článek kritizuje praxi českých soudů, které při zodpovídání žádostí na informace neprovádí žádné vyvažování práva na soukromí a práva na informace, namísto toho bez jakéhokoliv odůvodnění dogmaticky rozhodují na jednu či druhou stranu. Častěji na stranu, že je nutné trvat na úplné anonymizaci. Tento stav - nedostatek odưvodnění a selhání $v$ rozpoznání kolize dvou základních práv, jež je nutné prostřednictvím testu
\end{abstract}

1 Mgr. Bc. John A. Gealfow je studentem dvojího doktorského studia, které vykonává na École de droit de la Sorbonne v Paříži v oboru srovnávacího práva a na Právnické fakultě Masarykovy univerzity v oboru právní teorie. Jeho dizertační výzkum se věnuje tématu Princip právní jistoty a jeho role $v$ právním státu. Tento článek byl sepsán díky podpoře z projektu specifického výzkumu č. MUNI/A/0837/2017 s názvem „Informace o rozhodovací činnosti soudů v trestních věcech: teorie a praxe”, jež se věnuje empirickému zjištování faktické možnosti dostat se $\mathrm{k}$ informacím o rozhodovací činnosti českých soudů na základě zákona č. 106/1999 Sb., o svobodném přístupu k informacím.

2 Mgr. Christian May je advokátním koncipientem v advokátní kanceláři JUDr. Ivy Kremplové, kde se věnuje zejména obchodnímu právu a ochraně osobních údajů. 
proporcionality vyvažovat - je podle autorů článku porušením práva na informace.

\section{KLÍČOVÁ SLOVA}

právo na soukromí, svobodným př́stup $k$ informacím, anonymizace, př́stup $k$ soudním rozhodnutím, test proporcionality, otevřenost justice, informace o trestním odsouzení, informace o trestním ř́zení, kontrola veřejnosti

\section{ABSTRACT}

The extent of personal data anonymization contained in judgements of domestic courts has never been unified. The approach of individual courts depends on unclear criteria, which, from the point of view of current legislation, cannot be unequivocally determined. It is, however, possible to determine certain limits of the anonymization of personal data in court decisions using the analysis of basic principles of individual types of judicial proceedings together with principles of the right to the access to information, protection of personal data and philosophy of protection of human rights. This article criticizes the way in which Czech courts as public subjects obliged to provide information based on the Czech statute about free access to information for the reason that the courts fail to recognize that there can be no dogmatic answer about what type of personal data should be anonymized applicable to all cases. The courts fail to recognize the conflict between two human rights - right to privacy and right to the access to information. The courts must provide reasoning, which right should outweigh the other in particular case based on the circumstances of the information asked (e.g. information about publicly active person) and on the circumstances of the person demanding the information (motivation of the person and the purpose information will be used for, also the public interest in having the information public). Authors conclude that without proper reasoning about these criteria the constitutional right to the access to information is violated. 


\section{KEYWORDS}

right to privacy, free access to information, anonymization, access to judicial decisions, proportionality test, transparency of the judiciary, information about criminal conviction, information about criminal proceedings, public oversight

\section{1. ÚVOD}

Tento článek se zabývá otázkou anonymizace osobních údajů v trestních rozsudcích okresních soudů $\mathrm{v}$ České republice. Na interpretační problém a nekonzistentní praxi jsme narazili v rámci provádění empirického výzku$\mathrm{mu}$, který zkoumal problematiku přístupu $\mathrm{k}$ těmto rozhodnutím prostřednictvím práva na svobodný přístup $\mathrm{k}$ informacím. Předmětné rozsudky mají sloužit jako podkladový materiál pro empirický výzkum vyžadující demografické údaje o pachatelích trestných činů. $\mathrm{Z}$ toho důvodu byly soudy požádány o poskytnutí množiny rozhodnutí a provedení nižší míry anonymizace osobních údajů v nich obsažených. Naše konkrétní prosba směřovala $\mathrm{k}$ tomu, aby soudy neanonymizovaly rok narození pachatele trestného činu a jeho křestní jméno. Důvodem pro tento požadavek byl záměr zjistit, zda věk pachatele může mít vliv na výši uloženého trestu. Stejný důvod měl i náš požadavek na zachování křestního jména - pohlaví pachatele je také jednou z možných proměnných, které mohou soudce při ukládání trestu ovlivnit. Kvůli ne zcela vhodné praxi českých soudů, kdy soudní rozhodnutí často uvádí neutrální pojem „obžalovaný”, ač se jedná o ženu, jsme chtěli disponovat křestními jmény pachatelů, abychom měli jednoznačné vodítko $\mathrm{k}$ určení pohlaví pachatele.

Tento článek se nevěnuje samotnému empirickému výzkumu, jehož průběh a závěry jsou popsány $\mathrm{v}$ článku, který je předmětem recenzního řízení v jiném periodiku, nýbrž se věnuje řešení interpretačních problémů pro standardy ochrany osobních údajů při poskytování soudních rozhodnutí. Při vyhodnocování rozhodovací praxe týkající se poskytnutí informací jsme identifikovali velké interpretační rozdíly v míře anonymizace soudních rozhodnutí. To se projevuje $\mathrm{v}$ rozdělení soudů do dvou skupin. Na základě to- 
tožných žádostí některé soudy anonymizovaly veškeré osobní údaje v rozhodnutích s odkazem na zákon č. 101/2000 Sb., o ochraně osobních údajů, se stanoviskem, že na tomto podkladě dokonce mají povinnost veškeré údaje anonymizovat a nesmí z tohoto činit výjimky. Některé soudy část osobních údajů anonymizovaly, jejich postup však lze nazvat určitou „minimalistickou anonymizací". Tyto soudy anonymizovaly pouze část údajů a v rozhodnutí ponechaly údaje, u kterých jsme výslovně požádali o jejich neanonymizování. Zároveň uvedly upozornění, že se jedná o jistou benevolenci a že zbytek údajů se anonymizovat musí.

Tento příspěvek analyzuje právní úpravu pro zodpovězení otázky, za jakých okolností a zda vůbec má dojít $\mathrm{k}$ anonymizaci osobních údajů obsažených $\mathrm{v}$ soudních rozhodnutích. Je nutné $\mathrm{v}$ tomto ohledu vyvážit více různých ústavněprávních hodnot - je to právo na soukromí na jedné straně, na druhé straně je pak právo na informace, dále otevřenost justice, záruky této otevřenosti a možnost její kontroly, v neposlední řadě pak právo na svobodu projevu, pro jehož realizaci je dostupnost informací nezbytnou podmínkou.

Cílem tohoto článku je tak analýza argumentů, které pro zdůvodnění svého rozhodnutí různé soudy využily. Chceme normativně vyřešit otázku, který ze soudních táborů interpretoval právní úpravu anonymizace osobních údajů při uplatňování práva na informace správně a ústavně konformně. Je totiž zarážející, že jsme se ze strany soudní soustavy při stejných požadavcích argumentujících totožnou právní úpravou setkali se dvěma zcela odlišnými právními závěry, které si soudy vždy zdůvodnily platnou a účinnou právní úpravou. To ukazuje na existující interpretační problém, který se nám snad tímto článkem podaří alespoň částečně osvětlit.

\section{ANONYMIZACE OSOBNÍCH ÚDAJŮ PODLE ČESKÉHO PRÁVA}

Svobodný přístup k informacím je základním právem zaručeným čl. 17 Listiny základních práv a svobod. Tento článek ve svém odst. 4 obsahuje právní normu stanovující, že právo vyhledávat a šírit informace lze omezit zákonem, jde-li o opatření $\mathrm{v}$ demokratické společnosti nezbytná pro ochranu práv a svobod druhých, bezpečnost státu, veřejnou bezpečnost, 
ochranu veřejného zdraví a mravnosti. ${ }^{3} \mathrm{~V}$ př́padě osobních údajů v soudních rozsudcích bude relevantní hned první vymezený účel - ochrana práv a svobod druhých.

Jako v mnoha jiných případech, i zde se odehrává vyvažování mezi několika kolidujícími právy. ${ }^{4}$ Zatímco na jedné straně je legitimní získávat informace o činnosti státu a jeho orgánů (resp. nestátních nositelů a vykonavatelů veřejné moci), kolidujícím právem je zde soukromí osob, které jsou touto činností státu dotčeny nebo kterých se tato rozhodovací činnost týká. Tato dvě práva jsou na zákonné úrovni konkretizována - zákonem č. 106/1999 Sb., o svobodném prrístupu k informacím, a zákonem č. 101/2000 Sb., o ochraně osobních údajů. Alespoň touto právní úpravou se soudy měly řídit $\mathrm{v}$ době podávání žádostí o informace na začátku roku 2018. V mezidobí ještě vstoupilo v účinnost také Nařízení Evropského parlamentu a Rady 2016/679, o ochraně fyzických osob v souvislosti se zpracováním osobních údajů a o volném pohybu těchto údajů (dále jen "obecné nařízení o ochraně osobních údajů" či jen "Nařízení").

Zákon o svobodném prrístupu $\mathrm{k}$ informacím ve svém $\S 11$ odst. 4 písm. b) uvádí, že povinné subjekty neposkytnou informace o rozhodovací činnosti soudů $\mathrm{s}$ výjimkou rozsudků. $\mathrm{Z}$ toho lze a contrario dovodit, že soudy rozsudky musejí poskytnout. ${ }^{5} \mathrm{~V}$ našem př́padě pouze řešíme otázku,

3 Povahou práva na informace jako základního lidského práva se zabývá i s ohledem na mezinárodněprávní úpravu KOLMAN, Jiří. Právo na informace jako základní lidské právo. Právní prostor. Publikováno 7.1.2016, citováno dne 23.1.2016. Dostupné online: https://www.pravniprostor.cz/clanky/ustavni-pravo/pravo-na-informace-jako-zakladni-lidske-pravo

4 Základ pro teorii tohoto vážení mezi kolidujícími právy položil Robert Alexy, přičemž jeho teoriemi se inspirovaly mnohé ústavní soudy včetně toho českého. Více viz ČERVÍNEK, Zdeněk. Standardy přezkumu ústavnosti v judikatuře Ústavního soudu. Jurisprudence, č. 4, 2015, s. 22.

5 Sporné a kritizovatelné $\mathrm{v}$ této souvislosti je to, že rozsudek není jedinou formou rozhodnutí soudu, kterou se řízení končí. I usnesením se totiž někdy může rozhodovat meritorně. $\mathrm{Z}$ toho důvodu je tato právní norma někdy označována za nesystematickou a je navrhováno její vypuštění či změnu. $K$ tomu srov. FUREK, Adam. ROTHANZL, Lukáš. JIROVEC, Tomáš. Zákon o svobodném př́stupu $k$ informacím. Komentári. Praha: C.H. Beck, 2016, s. 543. Z perspektivy našeho empirického výzkumu chceme podotknout, že toto nám vůbec nečinilo problémy. Nesetkali jsme se $s$ jedinou instancí problému, kdy by nám soudy odmítly vydat trestní př́ḱkaz, kterým se někdy o spáchaném činu podle námi vymezených kritérií rozhodlo, protože by zastávaly názor, že je možné vydávat pouze rozsudky. 
v jakém rozsahu tak jsou povinny učinit. Součástí rozsudků jsou totiž taktéž osobní údaje soukromých osob, přičemž tyto osoby mohou být zpřístupněním svých údajů třetím osobám dotčeny na svých právech.

Na situaci, kdy žádaná informace obsahuje i osobní údaje, reaguje § 8a zákona o svobodném přístupu k informacím. Toto ustanovení stanovuje, že informace týkající se osobnosti, projevů osobní povahy, soukromí fyzické osoby a osobní údaje poskytne povinný subjekt pouze v souladu s právními předpisy, které upravují jejich ochranu. Ochrana těmto hodnotám je poskytována jak cestou soukromoprávní, tak cestou veřejnoprávní. Soukromoprávní ochrana je poskytována ustanoveními § 81-90 zákona č. 89/2012 Sb., občanský zákoník. ${ }^{6}$ Veřejnoprávní ochrana je v současné době poskytována zejména obecným nařízením o ochraně osobních údajů, v otázkách nekolidujících s touto evropskou právní úpravou i již téměř obsoletním zákonem o ochraně osobních údajů. ${ }^{7} \mathrm{~V}$ tomto ohledu je pak třeba zkoumat, $\mathrm{v}$ jakých případech a za jakých podmínek je poskytnutí osobních údajů $\mathrm{v}$ souladu s těmito předpisy.

\subsection{REZORTNÍ ÚPRAVA PRO OSOBNÍ ÚDAJE V ROZSUDCÍCH}

Je třeba zmínit ještě provádějící právní úpravu, která dopadá konkrétně na poskytování informací o rozhodovací činnosti soudů. Jedná se o Instrukci

${ }^{6}$ Na tomto místě je třeba podotknout, že projev osobní povahy je základním pojmem soukromoprávní ochrany osobnosti není totožný s pojmem osobní údaj. Oba tyto instituty mají samostatnou povahu, na druhou stranu může $\mathrm{v}$ konkrétních př́padech docházet $\mathrm{k}$ překryvu. FUREK, Adam. ROTHANZL, Lukáš. JIROVEC, Tomáš. Zákon o svobodném př́stupu $k$ informacím. Komentár. Praha: C.H. Beck, 2016, s. 393.

7 Odpověd na otázku, do jaké míry je zákon o ochraně osobních údajů stále účinný a do jaké míry obsoletní, by přesahovala možnosti tohoto článku. V krátkosti je ale možné říci, že Obecné nařízení se samozřejmě $\mathrm{z}$ hlediska své přímé použitelnosti a $\mathrm{z}$ hlediska přednosti evropského práva bude aplikovat primárně, zatímco zákon o ochraně osobních údajů je možné použít pouze $\mathrm{v}$ oblastech, které Obecné nařízení neupravuje. Úřad pro ochranu osobních údajů předpokládal, že situace, ve které se nacházíme, vůbec nenastane, protože před účinností Nařízení dojde k přijetí adaptačního zákona, který zákon o ochraně osobních údajů zruší. Srov. Základní příručka k GDPR. Úřad pro ochranu osobních údajů. Citováno dne: 23.1.2019. Dostupné online: https://www.uoou.cz/zakladni-prirucka-kgdpr/ds-4744/archiv $=0 \& p 1=4726$. Tak se nestalo, $v$ době psaní tohoto článku je návrh zákona o zpracování osobních údajů předložený Ministerstvem vnitra v srpnu 2017 teprve po druhém čtení v Poslanecké sněmovně. Tento návrh skutečně zákon o ochraně osobních údajů v § 65 ruší. Do té doby je ovšem tento zákon stále součástí právního řádu. 
Ministerstva spravedlnosti ze dne 24. července 2009, č.j. 13/2008-SOSV-SP, kterou se provádějí některá ustanovení zákona č. 106/1999 Sb., o svobodném přístupu $\mathrm{k}$ informacím (dále jen „Instrukce“). Tímto interním normativním předpisem Ministerstvo spravedlnosti jakožto dohlížející orgán nad resortem justice konkretizovalo úpravu zákona o svobodném přístupu $\mathrm{k}$ informacím za účelem zajištění jednotného postupu u jednotlivých povinných subjektů spadajících do resortu.

V naší záležitosti je podstatný zejména $§ 5$ odst. 4 Instrukce, podle kterého povinný subjekt $\mathrm{v}$ případě žádostí $\mathrm{o}$ informace, které směřují $\mathrm{k}$ pravomocným rozsudkům, posoudí, zda tento rozsudek obsahuje chráněné informace. Těmi jsou vedle osobních údajů také utajované informace, obchodní tajemství apod. Toto ustanovení také výslovně zakotvuje, že soud má vycházet $\mathrm{z}$ respektu $\mathrm{k}$ principu minimalizace a selekce, které jsou zakotveny $\mathrm{v} \S 12$ zákona o svobodném přístupu $\mathrm{k}$ informacím.

V § 6 odst. 7 Instrukce je obsažena další pro předmětnou problematiku důležitá norma, která stanoví rozsah anonymizace. Ta má probíhat tak, že povinný subjekt $\mathrm{v}$ záhlaví i samotném textu rozsudku znečitelní příjmení (vyjma iniciály), adresu a datum narození fyzických osob (s výjimkou jmen a př́ijmení soudců, státních zástupců, advokátů, znalců a jiných obdobných osob). Výslovně je stanoveno, že (křestní) jméno soud v rozsudku ponechá, ledaže by uvedení jména společně s částečně anonymizovaným př́jmením a obsahem rozsudku umožnilo snadnou identifikaci fyzické osoby, přičemž tato identifikace by představovala neoprávněný zásah do chráněného práva. Pokud by se tak stalo, soud má znečitelnit jak př́ijmení, tak jméno fyzické osoby na pouhé iniciály.

Již zde je tak možné konstatovat, že soudy, jež přistoupily $\mathrm{k}$ úplné anonymizaci, postupovaly v rozporu s touto Instrukcí tím, že nevyhověly žádosti o neanonymizování křestních jmen. Křestní jména by totiž neměla být anonymizována jako obecné pravidlo, bez ohledu na to, zda $\mathrm{k}$ tomu žadatel sdělil svoje stanovisko nebo nikoliv. U tak generického a častého trestného činu, jakým je krádež, je identifikace pachatele pouze na základě křestního jména a údajů obsažených v rozsudku prakticky vyloučena. I kdyby ovšem nebyla, soud by pochybil, pokud by nezdůvodnil, $\mathrm{z}$ jakých důvodů toto 
riziko spatřuje. V odůvodnění se tomuto nevěnoval žádný soud, který odmítl poskytnout neanonymizovaná křestní jména. ${ }^{8}$

Otázka roku narození je již složitější, protože výslovnou odpověd’ pro to, že se má rok narození poskytovat, již v Instrukci Ministerstva spravedlnosti nenalezneme. Větu, že povinný subjekt $\mathrm{v}$ záhlaví rozsudku i v samotném textu znečitelní datum narození fyzických osob, bychom mohli vykládat úzce či široce. Mohli bychom se ptát, zda výraz „datum” narození poukazuje skutečně pouze na datum $\mathrm{v}$ užším slova smyslu, tedy pouze měsíc a den, nebo jestli se datem narození myslí den, měsíc i rok. Snad naše předcházející teze nebude čtenářem vykládána tak, že se na tomto místě pokoušíme ohnout vcelku jasný termín „datum“, který se v běžné mluvě používá pro označení dne, měsíce i roku. Je totiž vhodné uvést, že se zveřejňováním roku narození zákon o svobodném přístupu $\mathrm{k}$ informacím principiálně nemá problém. Naopak kupř́kladu § 8b odst. 3 tohoto zákona rok narození výslovně vymezuje jako informace, které se mají poskytnout o př́ijemcích veřejných prostředků. I na základě zákona o svobodném př́stupu $\mathrm{k}$ informacím je tak rozlišováno mezi dnem a měsícem narození na jedné straně a rokem narození na straně druhé. Tento rozdíl pouze není reflektován Instrukcí.

Mohli bychom se na tomto místě pustit do rozsáhlého jazykového výkladu a zkoumání toho, $v$ jakých právních předpisech je legislativní termín „data” či „data narození” definován. Argumentace může totiž směřovat na obě dvě strany. Je ovšem třeba se ptát, proč je na jedné straně akcentován rozdíl mezi jménem a př́jmením, $\mathrm{u}$ data a roku narození ale tento rozdíl akcentovaný není, přičemž vliv na možnost identifikace je podobný.

Úmysl normotvưrce $\mathrm{v}$ př́ípadě Instrukce patrně směřoval $\mathrm{k}$ anonymizaci dne, měsíce i roku. Je ovšem otázkou, jestli v př́ípadě takto nejasného slovního spojení nemá převážit spiše výklad podle účelu právního předpisu

\footnotetext{
V případě našeho empirického výzkumu se jednalo o Obvodní soud pro Prahu 4 a Obvodní soud pro Prahu 2, které výslovně uvedly, že je nutné aplikovat Instrukci, ovšem přesto do šlo $\mathrm{k}$ anonymizaci křestních jmen. U mnoha dalších soudů došlo $\mathrm{k}$ anonymizaci, ovšem často bez jakékoliv úvahy či zmínky jakéhokoliv normativního předpisu vyjma obecného odkazu na zákon o ochraně osobních údajů.
} 
a výklad ústavně-konformní. Domníváme se, že tyto dvě výkladové metody poskytují stejnou odpověd'.

Jak bude vypadat teleologický výklad této právní normy? Účelem je na jednu stranu ochrana soukromí a osobních údajů fyzických osob, na druhou stranu se ale Instrukce snaží zjevně vyvážit toto právo i s právem na informace. Je sice možné argumentovat, že soukromá osoba nemůže disponovat žádným oprávněným zájmem na vědomosti o detailech soudního řízení týkajícího se jiné soukromé osoby. Těchto zájmů však může být více, v následující kapitole o účelu trestu se budeme touto otázkou ještě více zabývat a ukážeme, že i u soukromé osoby bez osobního zapojení může být legitimní zájem na informacích o trestním řízení jiné osoby. Na druhou stranu je ale třeba uvést, že k tomuto konfliktu mezi právem na soukromí a právem na informace vůbec nemusí dojít, pokud je anonymizace provedena - tedy pokud není možné identifikovat konkrétní osobu. Bez možnosti identifikovat konkrétní osobu totiž nemůže dojít ani k žádnému zásahu do práva na soukromí. ${ }^{9}$

Pokud se Instrukce Ministerstva spravedlnosti velmi pečlivě snaží vymezit případy týkající se anonymizace křestního jména, činí tak právě $\mathrm{z}$ toho důvodu, aby nebylo možné snadno identifikovat osobu, které se dané rozhodnutí týká. Proč by ale mělo dojít k takovému uvažování pouze u křestního jména, které samo o sobě není způsobilé identifikovat konkrétní osobu, když rok narození sám o sobě této identifikace není taktéž schopen? Když víme, že krádeže v Lidlu v Blansku se dopustil Petr M., který se narodil v roce 1973, samotný rok narození nám zásadní znalost nepřinese. $\mathrm{Z}$ toho důvodu se domníváme, že pokud je výchozím prístupem poskytování křestního jména (nejsou-li dány zvláštní důvody pro jeho neposkytnutí), pak by se měl taktéž poskytovat i rok narození (opět však pouze

\footnotetext{
9 Zde je samozřejmě možné podotknout, že možnost identifikace se těžko posuzuje dopředu, ovšem že s každým údajem obsaženým navíc se riziko identifikace zvyšuje. Touto otázkou se budeme zabývat ještě dále $\mathrm{v}$ textu, na tomto místě pouze uvádíme, že při nemožnosti identifikace osoby (např. při poskytnutí pouze zcela kusých informací či klidně i jména a př́ijmení, které jsou ovšem zcela běžné a zaměnitelné, jako např. Petr Novák, při anonymizaci apod.) se vůbec nejedná o zásah do práva na soukromí. V případě, kdy je identifikace možná, se již o zásah do práva na soukromí jedná, ovšem ještě se nemusí jednat o zásah nepř́ípustný, protože je nutné provést test proporcionality - viz dále.
} 
pokud nejsou dány důvody pro jeho neposkytnutí). Účelem právních předpisů upravujících právo na informace je informace poskytnout - limitem je to, pokud by poskytnutím bylo zasaženo do práv jiného. Bylo by v rozporu s tímto účelem, pokud by nebyla poskytnuta informace, která není způsobilá zasáhnout do práv jiného.

Stejný závěr dle našeho názoru poskytuje i ústavněprávní výklad. Na základě obecné teze, že při omezování jakéhokoliv základního práva do tohoto práva máme zasáhnout co nejšetrněji a udělat tento zásah co nejminimalističtější, můžeme totéž vyvodit i do zásahu do práva na informace. ${ }^{10}$ Právo na informace omezuje právo na soukromí. Pokud nebude soukromí konkrétní osoby zasaženo, není v souladu s ústavním pořádkem, dojde-li přesto $\mathrm{k}$ omezení práva žadatele na informace. ${ }^{11}$

Situace je pochopitelně komplikovanější tím, že soud nikdy nemůže vědět, jestli $\mathrm{k}$ identifikaci nakonec dojde nebo nedojde - jestli jsou informace pro identifikaci dostatečné nebo nedostatečné. Bavíme se pouze o určité míře rizika, která $s$ každým poskytnutým údajem pochopitelně roste. Přesto se domníváme, že paušální závěr o neposkytování roku

${ }^{10}$ Právo na informace je velmi úzce spojeno s právem na svobodu projevu, zejména v případě judikatury Evropského soudu pro lidská práva, protože Úmluva v čl. 10 zakotvuje zejména právo na svobodu projevu a právo na informace se dlouhou dobu vyvíjelo pouze jako př́ivažek, který se stal samostatným právem až po dlouhém judikatorním vývoji (srov. rozsudek ESLP ze dne 14. dubna 2009 ve věci Társaság a Szabadságjogokért proti Mad’arsku, č. 37374/05, a dále rozsudek ESLP ze dne 26. května 2009 ve věci Kenedi proti Mad’arsku, č. $31475 / 05$. O principech vyvažování práva na svobodu projevu a práva na soukromí ve vztahu ke zveřejňování informací o soukromém životě osob srov. KMEC, Jiří. KOSAŘ, David. KRATOCHVÍL, Jan. BOBEK, Michal. Evropská úmluva o lidských právech. Komentár̆. Praha: C.H. Beck, 2012, s. 910-912.

11 Jedná se o porušení podmínky vhodnosti, jakožto jedné ze tří podmínek testu nezbytnosti v demokratické společnosti, což je poslední bod tř́krokového testu proporcionality používaného Ústavním soudem. Vhodnost je způsobilost prostředku k dosažení účelu omezení, $\mathrm{v}$ tomto případě ale $\mathrm{k}$ naplnění účelu vůbec nedojde, protože omezením jedné ústavněprávní hodnoty nedojde ke zvýšené ochraně u ústavněprávní hodnoty jiné. $\mathrm{K}$ tomu srov. WAGNEROVÁ, Eliška In: WAGNEROVÁ, Eliška a kol. Listina základních práv a svobod Komentárr. Praha: Wolters Kluwer, 2012, s. 26, či KOSAŘ, David. Kolize základních práv v judikatuře Ústavního soudu ČR. Jurisprudence, č. 1, 2008, s. 7-8, ze kterého je možné zdưraznit zejména to, že krok identifikace základních práv, jež stojí v kolizi, může působit nadbytečně, je ale důležitý právě z toho hlediska, aby se nechránilo pouze jedno ze základních práv a vůbec se ani nezvážil důsledek pro jiné základní právo, které soud ve své úvaze vůbec nezohlednil. 
narození není ústavně konformní a není ani v souladu s principy, na kterých je postaven zákon o svobodném přístupu k informacím. Závěrečná myšlenka této kapitoly (a zároveň myšlenka prostupující celý článek) je, že $\mathrm{k}$ veškerému posuzování toho, jestli má dojít k poskytnutí informace, musí docházet s ohledem na konkrétní okolnosti a s přihlédnutím k riziku zjištění přesné totožnosti dotčené osoby, k oprávněnému zájmu žadatele, k veřejnému zájmu apod. Činit paušální závěry o poskytnutí konkrétního údaje bez uvažování nad konkrétními okolnostmi čistě z dikce právního předpisu (nota bene když předmětná Instrukce je pouhým interním normativním předpisem, není dokonce ani podzákonnou právní úpravou) ${ }^{12}$ je v rozporu s filozofií, na které je postaven ústavní pořádek, ochrana základních práv a ostatně i zákon o svobodném přístupu k informacím. ${ }^{13}$

12 Interní normativní akty nejsou prameny práva, i když mají normativní charakter. Jsou závazné na základě právních předpisů. Jsou závazné jen pro toho, kdo je na základě zákona účastníkem určitého vztahu, kterého se týkají (např. člen akademické obce či úředník ve služebním poměru). Srov. GERLOCH, Aleš. Teorie práva. 6. vydání. Plzeň: Aleš Čeněk, 2013, s. 73. Je ovšem třeba zdůraznit, že i interní normativní předpisy mají své působení na externí subjekty. Zaměstnanec úřadu např. nevydá určité rozhodnutí, pokud by to bylo v rozporu s jejich vnitřní instrukcí, i když tato instrukce je závazná pouze pro něj jako zaměstnance, nikoliv pro občana požadujícího vydání rozhodnutí. Existence tohoto interního normativního aktu tedy může zasáhnout do práv jednotlivce. Vzhledem $\mathrm{k}$ tomu, že zasahovat do práv a povinností jednotlivců ze strany státu je možné pouze na základě zákona, je i zde požadavek toho, aby založení práv a povinností bylo učiněno zákonnou úpravou a interní normativní instrukcí bylo toto pouze více specifikováno.

13 Obdobný případ, kdy byla obecným právním předpisem zakotvena povinnost anonymizovat veškeré osobní údaje, představují GRUODYTÉ, Edita. MILČIUVIENÉ, Saulé. Anonymization of Court Decisions: Are Restrictions on the Right to Information in "Accordance with the Law“?. Baltic Journal of Law \& Politics. Roč. 9, č. 2, 2016, s. 166. Autoři kritizují zakotvení této povinnosti v litevském právním řádu. Je třeba podotknout, že tato povinnost byla zakotvena rozhodnutím Justiční rady, dokonce tedy orgánem moci soudní. Svoji kritiku zakládají na obdobných důvodech, na kterých je založena argumentace tohoto článku - nedostatečnost vyvažování lidských práv a zároveň zasažení do samotného jádra práva na informace, které je podle autorů zcela potlačeno, nikoliv pouze omezeno. Navíc se přidává ještě prvek dělby moci a porušení předpokladu testu proporcionality o tom, že práva lze omezit pouze zákonem, zde je ale omezuje dokonce justiční orgán svým rozhodnutím. Zajímavé je také podotknout, že Česká republika se stala součástí analýzy autorů tím, že je jed na z poměrně malého počtu zemí Evropské unie (podle autorů společně s Nizozemím, Mad’arskem, Estonskem a Litvou), kde jsou soudní rozhodnutí anonymizována jako pravidlo, ze kterého jsou občasné výjimky. Tamtéž, s. 165. 


\subsection{DOVODILI BYCHOM STEJNÝ ZÁVĚR I NA ZÁKLADĚ ZÁKONNÉ ÚPRAVY?}

K výše uvedenému závěru jsme dospěli na základě interního normativního předpisu. Jedná se však o řešení, které není zcela uspokojivé, proto považujeme další analýzu problematiky za zcela nezbytnou. Jaká by nastala situace, kdyby předpis jako Instrukce Ministerstva spravedlnosti neexistoval? Nemusí se přitom jednat o samoúčelnou a hypotetickou otázku. Některé žadatele přitom mohou zajímat informace o rozhodovací činnosti orgánů samosprávy, státní správy, profesní samosprávy či jiných obdobných subjektů, v těchto rezortech se přitom ústřední orgány nemusely uchýlit $\mathrm{k}$ tvorbě podobné standardizační úpravy. $\mathrm{V}$ následujícím textu se pokusíme dovodit, že shodné stanovisko lze vyčíst i z obecné zákonné právní úpravy.

Existence úpravy jako je Instrukce Ministerstva spravedlnosti je žádoucí. Zákonná úprava je totiž nadmíru obecná a vyjma abstraktních klauzulí nám sama o sobě v popisovaných složitěǰš́ch otázkách odpověd’ nedává. Tomu ostatně přisvědčují i odpovědi soudů na naše žádosti o informace. $Z$ nich je patrné, že mnoho z nich o existenci Instrukce nemělo ani ponětí. ${ }^{14}$ Neradi bychom ale opomněli ještě jednu klíčovou otázku - a to totiž tu, že jakékoliv omezení základního práva by mělo být provedeno na základě zákona. ${ }^{15}$ $\mathrm{V}$ případě Instrukce, která má povahu interního normativního předpisu, má smysl se ptát, jestli je toto kritérium naplněno. Pokud by obsah Instrukce byl skutečně pouze provedením a konkretizací zákonných ustanovení, kritérium omezení zákonem by bylo splněno. Je ovšem třeba podotknout, že

${ }^{14} \mathrm{Z}$ celkem 67 př́padů, kdy soudy ve svém rozhodnutí argumentovaly právní úpravou anonymizace, byla tato Instrukce zmíněna pouze $v 7 \mathrm{z}$ těchto př́padů (konkrétně ji zmínily Obvodní soud pro Prahu 2, pro Prahu 3 a pro Prahu 4 a dále pak Okresní soud v Nymburce, v Kolíně, Kutné Hoře a Mělníku, všechny ostatní soudy se aplikací této směrnice výslovně nezabývaly a lze předpokládat, že mnoho z nich o její existenci ani neví). Zajímavé jsou př́ípady Obvodního soudu pro Prahu 2 a Obvodního soudu pro Prahu 4, které zdůrazňovaly nutnost aplikace Instrukce a nemožnost se od ní odchýlit (výslovně je zmíněno, že ačkoliv se nejedná o podzákonný předpis, jedná se o rezortní předpis, kterým jsou soudy vázány), přesto došlo k anonymizaci křestních jmen, přestože křestní jména být anonymizována nemají, pokud $\mathrm{k}$ tomu není zvláštní důvod. $\mathrm{V}$ tomto se ale domníváme, že pokud by soud takový důvod shledal, bylo by nutné toto výslovně zdůvodnit $\mathrm{v}$ rozhodnutí soudu, $\mathrm{k}$ čemuž nedošlo. Vyvozujeme z toho, že tyto dva soudy sice o existenci Instrukce vědí, ovšem důkladně se neseznámily s jejím obsahem a používají argumentaci o nutnosti její aplikace spíše jako floskuli, než že by skutečně aplikovaly její obsah. 
i přes naše převážně kladné hodnocení v předcházející kapitole je i úprava Instrukce poměrně restriktivní a dogmatická. I ona trpí tím, že pro některé př́pady zkrátka paušálně stanovuje, že má dojít $\mathrm{k}$ anonymizaci, ačkoliv to v konkrétním př́ípadě není důvodné.

Z komparativního hlediska je třeba připomenout jednu z mála právních norem našeho právního řádu, která konkretizuje otázku anonymizace soudních rozhodnutí. Nalezneme ji v § 59 odst. 3 zákona č. 182/1993 Sb., o Ústavním soudu, přičemž předmětem její úpravy je rozsah informací o rozhodovací činnosti Ústavního soudu, který se má uveřejnit ve Sbírce rozhodnutí. Je přitom třeba zmínit i historický vývoj tohoto ustanovení. Toto ustanovení totiž původně znělo: „Z každého nálezu se ve Sbírce rozhodnutí uveřejňují jeho výrok a taková část odůvodnění, ze které je zřejmé, jaký je právní názor Ústavního soudu a jaké duvody k němu vedly. Údaje o totožnosti účastníků a vedlejších účastníků, jejich zástupců, svědků a znalců se neuveřejňuji." S účinností od 1.1.2013 vlivem novely č. 404/2012 Sb. druhá věta tohoto ustanovení zní: „Údaje o totožnosti účastníků a vedlejších účastníků, jejich zástupců, svědků a znalců se neuveřejňují, stanoví-li tak zvláštní zákon nebo vyžadují-li to důležité zájmy těchto osob nebo státu anebo mravnost; rozhodnout o tom př́sluši tomu, kdo rridí vydávání Sbírky

15 Jedná se o tzv. test legality, který je součástí třetího kroku pětistupňového testu omezení základních práv Evropským soudem pro lidská práva. Porušení tohoto pravidla automaticky znamená zásah do základního práva. Srov. KMEC, Jiří. KOSAR̆, David. KRATOCHVÍL, Jan. BOBEK, Michal. Evropská úmluva o lidských právech. Komentáŕ. Praha: C.H. Beck, 2012, s. 104: „Shledá-li ESLP porušení principu legality u jednoho ustanovení Úmluvy, znamená to tak $v$ podstatě automaticky porušení i ostatních aplikovatelných ustanovení Úmluvy nebo Protokolů obsahujících tento princip.". V kontextu aplikace Úmluvy je třeba podotknout, že test legality pojímá právo ve smyslu materiálním a nikoliv formálním - zahrnuje sem psané jako obsahující jak podzákonné právní předpisy, tak i vyhlášky přijaté profesními komorami $\mathrm{v}$ rámci samosprávné působnosti stanovené zákonodárce. Je třeba doplnit, že je zde pnutí mezi českým překladem Úmluvy a jejím anglickým zněním. Judikatura ESLP se vydala tím směrem, že omezení musí být stanovena právem a musí být v souladu s právem, nikoliv že toto omezení musí být provedeno přímo zákonem. KMEC, Jiř́i. KOSAŘ, David. KRATOCHVÍL, Jan. BOBEK, Michal. Evropská úmluva o lidských právech. Komentáŕ. Praha: C.H. Beck, 2012, s. 106 cituje rozhodnutí Sanoma Uigevers B. V. proti Nizozemsku. I obecný normativní akt jako akt vydaný profesními organizacemi či dokonce věstníky vydané rektorem univerzity v Leyla Sahin proti Turecku jsou právem. Komponentami kvality práva jsou přitom dostupnost práva a předvídatelnost práva, dostatečné záruky před svévolnou aplikací práva. KMEC, Jiří. KOSAŘ, David. KRATOCHVÍL, Jan. BOBEK, Michal. Evropská úmluva o lidských právech. Komentár. Praha: C.H. Beck, 2012, s. 107-109. 
rozhodnutí."16 Je zde tedy vidět posun od zásadního nezveřejňování údajů o totožnosti $\mathrm{k}$ jejich zveřejňování, pokud zde nejsou konkrétní důvody pro nezveřejnění. Znění tohoto ustanovení se projevilo i v tom, jaké údaje o totožnosti jsou nyní zjistitelné $\mathrm{z}$ databáze rozhodnutí Ústavního soudu NALUS. Od roku 2013 jsou v této databázi na základě vykládaného ustanovení dostupné jméno, př́ijmení a akademický titul účastníků a vedlejších účastníků.

To opět ukazuje na výraznou restriktivnost Instrukce, pokud ta z nezveřejňování př́ijmení nečiní žádné výjimky, přestože zákonná právní úprava má (ač $\mathrm{v}$ jiném případě) zveřejňování př́ijmení dokonce jako obecné pravidlo, pokud zde nejsou konkrétní důvody proti tomuto zveřejnění. Možnost zásahu do soukromí dotčené osoby je úplně stejná, jedná se taktéž o zveřejňování informací o soudním řízení.

To je jenom dalším důvodem zabývat se přímo zákonnou úpravou a jejím ústavně-konformním výkladem, protože se zdá, že Instrukce přes některé své výhody patrně postupuje nad rámec zákona, a není tak splněna podmínka, že $\mathrm{k}$ omezení základního práva musí docházet $\mathrm{v}$ rámci zákona. ${ }^{17}$

Při uplatňování práva na informace jsme také došli k závěru, že na základě současné zákonné úpravy specifikované Instrukcí Ministerstva spravedlnosti soudy zkrátka učiní o anonymizaci osobních údajů jakýkoliv závěr, jaký chtějí učinit, a to prakticky bez zdůvodnění. Právě z toho vychází diametrální roztř̌ištěnost rozhodování soudů v př́ípadech našich žádostí, které

16 BRENKA, Gabriel. Nová úprava anonymizace rozhodnutí Ústavního soudu. brenka.eu. Publikováno dne 18. 9. 2013. Citováno dne 31. 10. 2018. Dostupné online: http://brenka.eu/nova-uprava-anonymizace-rozhodnuti-ustavniho-soudu/

17 V tomto je možné odkázat na FUREK, Adam. ROTHANZL, Lukáš. JIROVEC, Tomáš. Zákon o svobodném př́stupu $k$ informacím. Komentár̆. Praha: C.H. Beck, 2016, s. 396, podle kterého i na základě zákona o svobodném přístupu $\mathrm{k}$ informacím nemá ochrana osobních údajů absolutní přednost před právem na informace. Autoři komentáře uvádí: „Jak ovšem ukazuje soudní rozhodovací praxe, ani rozsáhlé hájemství zákonem koncipované ochrany osobních údajů nemusí vést ve v̌̌ech př́padech $k$ závěru o prednosti této ochrany před právem na informace. Jinak řečeno, navzdory zákonem založenému vztahu mezi právem na informace a ochranou osobních údajů ( $k$ tomu podrobněji níže) nelze ve všech př́padech vycházet z předpokladu absolutní aplikační přednosti ochrany osobních údajů před právem na prístup k informacím." Paušální závěr Instrukce o tom, že právo na soukromí ve své podobě ochrany osobních údajů má absolutní přednost, je tedy v rozporu s právní úpravou, kterou má pouze $\mathrm{v}$ jejích mezích provádět. 
byly ovšem naprosto totožné. Soudy činily obecné výroky, dle kterých údajně musí na základě zákona o ochraně osobních údajů anonymizovat veškeré údaje, přestože tento zákon takto striktní (a navíc v podání soudů velmi přesně definované) stanovisko neobsahuje. Zákon o ochraně osobních údajů i směrnice, kterou tento zákon implementoval ${ }^{18}$, byly založeny na stejné filozofiii. ${ }^{19}$ Obecné nařízení o ochraně osobních údajů opět přebírá stejné principy. ${ }^{20}$

Uvedený postup soudů je jednoznačně špatný - nejde čistě jenom o nedostatek odůvodnění $\mathrm{v}$ tomto rozhodnutí, což je problém sám o sobě, problémem je i to, že se těmito otázkami soudy nezabývají ani vnitřně jejich rozhodnutí jsou patrně činěna na základě intuicí těch, kdo dané rozhodnutí píší, a to bez seznámení se s obsahem právní úpravy a bez úvahy nad tím, že se zabývají kolizí dvou základních práv a že tomu by také mělo odpovídat to, čemu se ve svém uvažování věnují. ${ }^{21}$ Ústavní soud ve své judikatuře široce pojednává o tom, jak základní práva působí zprostředkovaně skrze jednotlivé normy podústavního práva tak, že „prozařují” podústavním právem ${ }^{22}$, a že soudy jsou povinny toto prozařování pečlivě vážit a brát $\mathrm{v}$ potaz tak, aby při výkladu či aplikaci norem podústavního práva zároveň chránily základní práva. ${ }^{23} \mathrm{Z}$ nálezu, ze kterého pochází poslední vyjádřená myšlenka, lze připomenout $\mathrm{i}$ to, že $\mathrm{v}$ případě kolize základních práv jako principů (na rozdíl od př́padu konfliktu norem podústavního práva) se Ústavní soud ř́́dí př́íkazem k optimalizaci, tj. postulátem minima-

18 Směrnice Evropského parlamentu a Rady 95/46/ES ze dne 24. října 1995, o ochraně fyzických osob v souvislosti se zpracováním osobních údajů a o volném pohybu těchto údajů (dále jen „Směrnice“).

19 Princip proporcionality byl zakotvený v čl. 6 odst. 1 písm. c) a v čl. 7 písm. c) a e) Směrnice. V tomto je možné odkázat na judikaturu Soudního dvora EU. V rozsudku ve spojených věcech C-92/09 a C-93/09 ze dne 9. listopadu 2010 Soudní dvưr uvedl, že právo na ochranu osobních dat není absolutním právem, ale musí být posuzováno ve vztahu k jeho funkci ve společnosti. Toto bylo dále rozvedeno rozsudkem ze dne 6. října 2015 ve věci Schrems (C-362/14), kde bylo konstatováno, že národní dozorové orgány musí zajistit spravedlivou rovnováhu mezi dodržováním základního práva na soukromí na straně jedné, a zájmy vyžadujícími volný pohyb osobních dat na straně druhé.

${ }^{20}$ Zejména je opět možné odkaz na čl. 5 odst. 1 písm. c) Nařízení, které zakotvuje přiměřenost a relevantnost osobních údajů společně s omezením na nezbytný rozsah ve vztahu k účelu, pro který jsou zpracovávány. 
lizace omezení základního práva a svobody, příp. veřejného statku. ${ }^{24} \mathrm{Je}$ potřeba s přihlédnutím ke všem okolnostem pečlivě zvážit, zda není jednomu základnímu právu dávána neoprávněně přednost před druhým, přičemž musí být současně šetřeno smyslu a podstaty základních práv (čl. 4 odst. 4 Listiny). K tomuto posouzení je třeba aplikovat test proporcionality (posouzení potřebnosti, vhodnosti a proporcionality v užším smyslu). ${ }^{25}$

\section{JAKÝMI KRITÉRII BY SE MĚLY POVINNÉ SUBJEKTY}

\section{ZABÝVAT?}

Jakmile jsou v dokumentu, který má být poskytnut v rámci práva na informace, uvedeny osobní údaje, jedná se o kolizi dvou lidských práv. V ta-

${ }^{21}$ Zajímavé je zde zjištění, že některé soudy se specifikem toho, jakou volnost mají při ano nymizaci, zabývaly ve svém rozhodnutí, i když ještě námi požadované rozsudky př́mo neposkytovaly, a nemůžeme se tedy o jejich př́stupu přesvědčit v praxi (jednalo se obvykle o rozhodnutí o stanovení výše úhrady nákladi̊, proti němuž jsme v mnoha případech podávali stížnost $\mathrm{k}$ Ministerstvu spravedlnosti jakožto nadřízenému orgánu). Celkem v 8 případech byl učiněn závěr o bezpodmínečné paušální anonymizaci. $\mathrm{Z}$ toho tedy vyplývá, že by $\mathrm{k}$ žádnému vyvažování základních práv nemohlo dojít - tyto soudy by patrně zastávaly stanovisko, že vyvážení provedl již zákonodárce při tvorbě právních norem. $\mathrm{K}$ úplné anonymizaci včetně křestních jmen (a tedy v rozporu s Instrukcí) došlo však dokonce ve 13 případech. Naší žádané „minimalistické“ anonymizaci bylo vyhověno v 6 případech, kdy bylo poskytnuto jak křestní jméno, tak rok narození. Nutnost provést test proporcionality byla $\mathrm{v}$ teoretické rovině (před tím, než byla rozhodnutí ještě poskytnuta) zmíněna pouze jednou. $\mathrm{Z}$ naší perspektivy lze však dovodit, že se testem proporcionality zabývaly všechny soudy, které vyhověly naší žádosti o minimalistickou anonymizaci. Zajímavý je případ Obvodního soudu pro Prahu 7 a Obvodního soudu pro Prahu 8, které anonymizovaly pouze křestní jméno (přes naši výslovnou žádost a přes znění Instrukce), ovšem ponechaly neanonymizovaný rok narození. Není přitom patrné, jaký právní podklad pro toto své rozhodnutí použily. Ještě zajímavější je případ Okresního soudu v Litoměřicích, který provedl úplnou anonymizaci, ovšem provedenou technicky špatně, tedy tedy ponechal veškeré osobní údaje zobrazitelnými. Tím myslíme zcela všechny osobní údaje - celé jméno a př́imení, data narození, místa bydliště i kontaktní adresy.

${ }^{22}$ Z mnohých nálezů lze zmínit např. nález Ústavního soudu ze dne 14. července 2004, sp. zn. I. ÚS 185/04, či nález ze dne 19. července 2016, sp. zn. Pl. ÚS 20/15. K rozsáhlému teoretickému pozadí $\mathrm{k}$ otázce prozařování lidských práv se všemi výhodami i riziky této koncepce srov. KÜHN, Zdeněk. Aplikace práva ve složitých př́padech - $k$ úloze právních principů $v$ judikatuře. Praha: Nakladatelství Karolinum, 2002, s. 159 a násl.

${ }^{23}$ Srov. nález Ústavního soudu ze dne 12. března 2008, sp. zn. Pl. ÚS 83/06. K tomu ještě detailněji viz WAGNEROVÁ, Eliška. In: WAGNEROVÁ, Eliška a kol. Listina základních práv a svobod Komentár. Praha: Wolters Kluwer, 2012, s. 22.

${ }^{24} \mathrm{~K}$ testu minimalizace zásahu do základního práva srov. KOSAŘ, David. Kolize základních práv v judikatuře Ústavního soudu ČR. Jurisprudence, č. 1, 2008, s. 9-10. 
kovém př́ípadě nezbývá než provádět jejich poměřováníi ${ }^{26}$, přičemž $\mathrm{k}$ tomuto musí přistoupit i , ,řadový” povinný subjekt, tím spíše soud. ${ }^{27}$

$\mathrm{V}$ tomto ohledu je hned několik možných kritérií, která by měl soud zvážit při tom, kdy rozhoduje o anonymizaci a jejím rozsahu. Měla by to být kritéria rozpoznatelnosti podle osobních údajů, pohnutky žadatele, a dále také zájem žadatele či veřejnosti na znalosti těchto údajů.

\subsection{ROZPOZNATELNOST TOTOŽNOSTI OSOBY PODLE OSOBNÍCH ÚDAJU゚}

O rozpoznatelnosti totožnosti osoby již bylo pojednáno $\mathrm{v}$ předcházejících kapitolách. Zkoumání tohoto kritéria by mělo znamenat to, jestli na základě zveřejněných údajů bude možné identifikovat konkrétní fyzickou osobu a spojit ji se skutky, které jsou popsány v předmětném rozhodnutí.

$\mathrm{V}$ případě, že rozpoznání na základě těchto údajů možné není, pak je odpověd jednoznačná - už by nemělo docházet k další anonymizaci, nebot by se jednalo o anonymizaci nadbytečnou. Zaprvé by navyšovala náklady

${ }^{25} \mathrm{~K}$ tomu srov. WAGNEROVÁ, Eliška. In: WAGNEROVÁ, Eliška a kol. Listina základních práv a svobod Komentář. Praha: Wolters Kluwer, 2012, s. 26. „Smyslem př́kazu proporcionality je zjistit, aby nebyla výhrada zákona použita $k$ vyššímu než opravdu nutnému omezení základních práv." Vhodnost jako způsobilost prostředku k dosažení účelu, potřebnost jako nutnost použití právě a jenom zákonodárcem vybraného prostředku a proporcionalita v užším smyslu jako přiměřenost zákonodárcem vybraného prostředku $\mathrm{v}$ relaci $\mathrm{k}$ dotčenému právnímu statku. Shodně viz KMEC, Jiří. KOSAŘ, David. KRATOCHVÍL, Jan. BOBEK, Michal. Evropská úmluva o lidských právech. Komentár̆. Praha: C.H. Beck, 2012, s. 81, který ještě rozlišuje kritérium nezbytnosti v demokratické společnosti v judikatuře Ústavního soudu a v judikatuře Evropského soudu pro lidská práva, u kterého podle něj panuje nekonzistence a jedná se o černou skříňku. Srov. KMEC, Jiří. KOSAŘ, David. KRATOCHVÍL, Jan. BOBEK, Michal. Evropská úmluva o lidských právech. Komentár̆. Praha: C.H. Beck, 2012, s. 114-115. Projev v judikatuře Ústavního soudu pak srov. např. nález Ústavního soudu ze dne 1. března 2007, sp. zn. Pl. ÚS 8/06, § 28.

${ }^{26}$ V nálezu ze dne 20. června 2006, sp. zn. Pl. ÚS 38/04, stejně jako v nálezu ze dne 13 . srpna 2002, sp. zn. Pl. ÚS 3/02, Ústavní soud konstatoval, že v případech střetů základních práv či svobod s veřejným zájmem, resp. jinými základními právy či svobodami, je třeba posuzovat účel (cíl) takového zásahu ve vztahu k použitým prostředkům, přičemž měřítkem pro toto posouzení je zásada proporcionality (přiměřenosti v širším smyslu), jež může být také nazývána zákazem nadměrnosti zásahů do práv a svobod.

${ }^{27}$ K otázce ochrany základních práv soudní soustavou srov. nález Ústavního soudu ze dne 21. ř́jna 2008, sp. zn. IV. ÚS 1735/07. 
poskytnutí informace, ${ }^{28}$ zadruhé by se jednalo o omezování práva na informace o informace, jejichž povaha nevylučuje jejich poskytnutí - $\mathrm{z}$ těchto dvou důvodů se tedy jedná o porušení práva na informace.

I v př́ípadě, že povinný subjekt dojde $\mathrm{k}$ názoru, že na základě osobních údajů je možná identifikace konkrétní fyzické osoby, ještě to neznamená, že $\mathrm{k}$ anonymizaci má dojít. ${ }^{29}$ Je totiž třeba zkoumat ještě další aspekty, které mohou poskytnutí této informace odůvodnit. Řeč přitom není pouze o datu a měsíci narození - tyto údaje žadateli patrně $\mathrm{k}$ ničemu nebudou a není zde důvod, proč by je měly soudy poskytovat. Představme si ale osoby s netypickým jménem a př́jmením. Je rozdíl mezi jménem Jan Novák a Chuck Wilson, alespoň $\mathrm{v}$ českém prostředí. Zatímco $\mathrm{v}$ případě jména Chuck nám bude pravděpodobně pouze toto jméno ve spojení identifikací soudu, který řízení vedl, postačovat $\mathrm{k}$ identifikaci, o jakého Chucka se jedná. Na druhou stranu podle jména Jan Novák patrně není možnost poznat, zvláště ne $\mathrm{v}$ případě tak genericky určené kriminality jako krádež hotovosti, o jakého Jana Nováka se jedná, a to často ani s jeho rokem narození.

Přesto, že Chucka z výše uvedeného příkladu jsme schopní identifikovat, není to sám o sobě důvod, abychom jeho jméno anonymizovali - může zde existovat konkurující zájem, který může poskytnutí informace odůvodňovat. Zejména se jedná o zájem vědecký, resp. výzkumný, či jiný veřejný zájem, o nichž bude pojednáno níže.

${ }^{28}$ Je totiž třeba podotknout, že v době psaní tohoto článku je i judikaturou Nejvyššího správního soudu akceptovaná hranice pro náklady anonymizace dokumentů až 10 Kč na stranu (tento výpočet vychází z akceptované hranice 3 minuty na jednu stranu rozhodnutí, přičemž podle Instrukce Ministerstva spravedlnosti ze dne 14. července 2011, č.j. 286/2011-OT-OSV, kterou se stanoví sazebních úhrad za poskytování informací, je hodinová sazba při poskytování informací 200 Kč na hodinu). Při dvacetistránkovém rozhodnutí se jedná o 200,- Kč za jedno takové rozhodnutí, což už zejména v případě, kdy žadatel potřebuje takových rozhodnutí víc, řekněme kvůli svému akademickému zájmu o danou oblast práva, poměrně vysoká částka. $V$ případě, že je tato hodnota vynakládána zcela zbytečně, protože ani na základě neanonymizovaných údajů by nebylo možné konkrétní osobu rozpoznat, se jedná o porušení žadatelova práva na informace.

${ }^{29}$ Ostatně i z judikatorní praxe Ústavního soudu můžeme vidět, že právo na soukromí může být omezeno právem na informace, jak se stalo např̀ v nálezu Ústavního soudu ze dne 15.11.2010, sp. zn. I. ÚS 517/10, v němž Ústavní soud dospěl k tomu, že je zde legitimní zájem veřejnosti na tom vědět o členství soudů v KSČ před rokem 1989, přestože tato informace má povahu osobního údaje. 


\subsection{POHNUTKY ŽADATELE O INFORMACE}

Zákon o svobodném přístupu obecně vylučuje, aby pohnutky žadatele hrály nějakou roli v tom, jestli bude informace poskytnuta nebo ne. Nejvyšší správní soud judikoval, že povinný subjekt není oprávněn jakkoli zkoumat a zabývat se otázkou účelnosti a důvodnosti žadatelovy žádosti či jeho motivy. ${ }^{30}$ Žádost o informace nemusí být nijak zdůvodněna, což je rozdílem např. od nahližení do spisu, kdy je nutné prokázat právní zájem nebo jiný vážný důvod. ${ }^{31}$ Jedná se ovšem toliko o obecné pravidlo k poskytování informací.

Domníváme se, že při rozhodování o míře anonymizace $\mathrm{v}$ rozsudku je posuzování pohnutek žadatele zcela namístě, a to právě s ohledem na existenci dvou kolidujících práv. Zájem na poskytnutí informace a záměr, jaký $s$ těmito informacemi žadatel má, může být muška na vahách, která odůvodní to, že by k anonymizaci nemělo docházet.

Rozdíl mezi seriózním akademickým zájmem na zkoumání soudních rozhodnutí a související potřebou znalostí demografických údajů o pachatelích trestných činů, a zájmem na budování databáze odsouzených osob je jednoznačně patrný. Vědecký výzkum často sám o sobě poskytuje záruky anonymity, a to zejména s ohledem na autoritu institucí, které za tímto výzkumem stojí a na jejichž půdě se výzkum provádí. Toto platí zejména $\mathrm{v}$ př́ípadech, kdy je př́slušný výzkum prováděn interně, tedy výhradně zaměstnanci dané instituce, členy akademické obce apod. Hlavním mechanismem,

${ }^{30}$ Srov. rozsudek Nejvyššího správního soudu ze dne 27. června 2007, sp. zn. 6 As 79/200658. S ohledem na kolizi práva na soukromí a práva na informace (což je zejména s ohledem na téma tohoto článku relevantní) v případě platů úředníků pak také rozsudek ze dne 22 . ř́jna 2014, sp. zn. 8 AS 55/2012-62. Nelze ovšem ani nezmínit dva nálezy Ústavního soudu z relativně nedávné doby, které se obsahem tohoto judikátu zabývaly a u kterých se může zdát, že zaujaly opačné stanovisko. Jedná se o nález ze dne 17. října 2017, sp. zn. IV. ÚS 1378/16, jehož závěry byly ještě potvrzeny dalším nálezem ze dne 3 . dubna 2018, sp. zn. IV. ÚS 1200/16. Zejména v prvně zmiňovaném nálezu Ústavní soud vznesl posléze rozporuplně přijímanou tezi o tom, že se účel žádosti o informace a motivace $\mathrm{k}$ získání těchto informací zkoumat má. $\mathrm{K}$ tomu zaujmeme stanovisko ještě dále, už zde je třeba uvést, že se nedomníváme, že by tyto dvě teze byly v rozporu, protože se principiálně vyjadřují k odlišným otázkám.

31 JELÍNKOVÁ, Jitka. TUHÁČEK, Miloš. Zákon o svobodném př́stupu $k$ informacím. Praktický komentáŕ. Praha: Wolters Kluwer, 2017, s. 6. 
který v takovém př́ípadě zajištuje diskrétnost při práci s osobními údaji, je pracovněprávní či disciplinární odpovědnost. Potenciální zveřejnění výsledků takového výzkumu pochopitelně není bez dalšího vyloučeno, avšak osobní údaje obsažené ve výstupu by měly být náležitě anonymizovány, není-li pro jejich ponechání zvláštního důvodu, viz kap. 3.3. Konečné zvážení toho, jestli pouhé spojení žadatele s výzkumnou institucí poskytuje dostatečnou úroveň ochrany osobních údajů, ovšem je samozřejmě v diskreci povinného subjektu. Naší tezí zde je pouze to, že úplná absence odůvodnění v této oblasti opět zasahuje do základních práv žadatele.

Ačkoliv se povinné subjekty pod vlivem výše zmíněné judikatury Nejvyššího správního soudu o irelevanci pohnutek žadatele zdráhají dotazovat žadatelů na to, jak poskytnuté informace plánují zpracovat, domníváme se, že $\mathrm{v}$ případě poskytování osobních údajů je tento dotaz zcela namístě. Pokud o osobní údaje v soudním rozhodnutí žadatel požádá, a přitom nezdůvodní zájem, který ho $\mathrm{k}$ tomu vede (což se ovšem většinou děje), je podle našeho názoru dotaz na tento zájem zcela legitimní.

Podobné stanovisko zaujal Ústavní soud, když posuzoval otázku poskytování informací o platech úředníků. Ústavní soud se věnoval kritériu role žadatele a konstatoval, že pokud někdo zaměřuje pozornost na věci veřejného zájmu, jde o výkon role veřejného „hlídacího psa“. Taková osoba může být charakterizována jako sociální „hlídací pes“ zasluhující stejnou ochranu jako je přiznávána tisku. ${ }^{32}$ Důležité je tudíž posouzení otázky, zda žadatel o informaci takto koná s cílem informovat veřejnost jako „veřejný hlídací pes“. Znamená to tedy, že tato role nemusí být vykonávána výlučně jen tiskem či nevládními organizacemi. ${ }^{33}$

Rozporuplné přijímání zmíněného nálezu Ústavního soudu odbornou veřejností je způsobeno zejména představou, že tento nález mění zavedenou praxi týkající se nutnosti neprokazovat důvody zájmu a motivaci při uplatňování práva na informace. Domníváme se však, že taková interpretace zmíněné judikatury by byla chybná. Důvodem, proč se Ústavní soud prokazováním těchto důvodů zabýval, je, že se jednalo o vyvažování dvou

32 Nález Ústavního soudu sp. zn. IV. ÚS 1378/16 ze dne 17. října 2017, § 90.
${ }_{33}$ Tamtéž, § 92. 
lidských práv. Tuto judikaturu je podle nás nutné vykládat způsobem, dle kterého je $\mathrm{v}$ případě kolize dvou lidských práv, popř. jiného veřejného zájmu, nutné přistoupit $\mathrm{k}$ vyvažování těchto hodnot. K vyvážení těchto hodnot může dojít pouze tehdy, disponuje-li povinný subjekt dostatkem $\mathrm{k}$ informací $\mathrm{k}$ tomu, aby toto vyvážení mohl provést. Jednotlivá lidská práva totiž mají $\mathrm{v}$ různých situacích různou úroveň ochrany, jak Ústavní soud ostatně konstatoval i ve své judikatuře týkající se kolize mezi právem na soukromí a svobodou projevu. To, kdo projev činí a z jakých důvodi̊, má vliv na to, zda je jeho právo na svobodu projevu hodno větší či menší ochrany a zda převáží nad právem na soukromí dotčené osoby. ${ }^{34}$ Stejně je bezpochyby nutné postupovat i v případě kolize mezi právem na informace a právem na soukromí. ${ }^{35}$ Naopak v př́ípadě „běžných” žádostí o informace požadující poskytnutí informací např. o stavbě budovy za prostředky obce nebo $\mathrm{v}$ případě žádosti o vydání rozhodnutí, v němž budou veškeré osobní údaje anonymizovány, by se mělo nadále setrvat na ustáleném závěru, že není potřeba prokazovat důvod a účel žádosti o informace, ani jak informace budou použity. To právě $\mathrm{z}$ důvodu, že $\mathrm{v}$ takovém případě neexistuje kolidující hodnota.

Je třeba uvést také to, že jistá zdrženlivost povinných subjektů ohledně poskytovaných údajů, které mohou potenciálně zasáhnout do práv jiného,

${ }^{34}$ Za př́klad je možné uvést známý nález Ústavního soudu ze dne 15. března 2005, sp. zn. I. ÚS 367/03, populárně známý jako Rejžek vs. Vondráčková, ve kterém soud uzavírá: „Lze obecně konstatovat, že osoby veřejně činné, tedy politici, veřejní činitelé, mediální hvězdy aj., musí akceptovat větši míru veřejné kritiky než jiní občané." Velmi podobně pak i v nálezu ze dne 17. července 2007 , sp. zn. IV. ÚS 23/05, ve kterém Ústavní soud řešil kolizi mezi právem na svobodu projevu novinářky a právem na soukromí soudkyně, o kárném řízení s níž novinářka natočila reportáž. V obou dvou případech Ústavní soud konstatoval, že právo na soukromí u veřejně činných osob má nižší míru ochrany. Není důvod, proč stejný závěr nevztáhnout kromě práva na svobodu projevu i na právo na informace.

35 Dva výše zmiňované nálezy ostatně nejsou jediné. WAGNEROVÁ, Eliška. In: WAGNEROVÁ, Eliška a kol. Listina základních práv a svobod Komentářr. Praha: Wolters Kluwer, 2012, s. 436, v této záležitosti uvádí klíčový nález Ústavního soudu ze dne 15. listopadu 2010, sp. zn. I. ÚS 517/10, ve kterém je uvedeno: „Ústavní soud zastává názor, že musí být jednoznačně rozlišeno mezi žádostí o informaci způsobilou prispět $k$ diskuzi $v$ demokratické společnosti týkající se veřejného zájmu, a informováním o detailech soukromého života jednotlivce, který nadto kupř. nevykonává veřejnou funkci. Veřejnost má právo být informována, což je základní právo $v$ demokratické společnosti, které se müže za určitých okolností dotýkat i soukromého života osob veřejně činných." 
je pochopitelná. Setrváme-li u našeho př́ípadu týkajícího se vydání trestních rozsudků s neanonymizovanými osobními údaji pachatele: na jednu stranu platí, že pokud by žadatel porušil právní předpisy o ochraně osobních údajů jejich neoprávněným zpracováním, např. tím, že by veškeré soudem poskytnuté informace zveřejnil, jednalo by se o porušení ochrany osobních údajů na jeho straně a bylo by možné sankcionovat přímo žadatele. Na druhé straně je pochopitelné, že se soudy snaží těmto situacím předcházet a takové údaje nepředávat právě s ohledem na obavy ohledně povahy reálné pohnutky žadatele.

Poskytnutí soudního rozhodnutí je zcela jistě zpracování osobních údajů podle Obecného nařízení. $\mathrm{K}$ tomuto poskytnutí však existuje titul. Tímto titulem je již zmiňovaný § 11 odst. 4 písm. b) zákona o svobodném př́istupu k informacím, podle kterého mají povinné subjekty poskytnout soudní rozsudky, tedy s ohledem na čl. 6 odst. 1 písm. c) Obecného nařízení se jedná o zpracování pro splnění právní povinnosti, která se na správce vztahuje.

Následné zveřejnění těchto údajů žadatelem by již však bylo další zpracování, které by tentokrát prováděl žadatel, k čemuž by však sám musel disponovat určitým právním titulem. Za předpokladu, že žadatel provádí určitý akademický výzkum, přičemž zveřejní pouze výsledky tohoto výzkumu, nicméně datový soubor obsahující osobní údaje uschová pouze pro povolané vědecké pracovníky, typicky opět př́slušné zaměstnance dané instituce či oprávněné členy akademické obce (viz výše), jedná se o zcela jiný př́pad.

Jak již ale bylo uvedeno, chápeme zdrženlivost soudu v této oblasti, nebot vytvoření databáze trestně odsouzených osob na základě údajů, které poskytl některý ze soudů, by jistě bylo z mediálního hlediska břemenem, které by dopadlo právě na tento soud, a to bez ohledu na to, jaká je jeho právní odpovědnost za takové zpracování osobních údajů.

Lze si dokonce představit situaci, kdy si povinný subjekt od žadatele vyžádá určité záruky dostatečné ochrany poskytnutých osobních údajů, zvláště pokud se jedná o zvláštní kategorie osobních údajů. Je totiž pravděpodobné, že by Úřad pro ochranu osobních údajů v případě zahájeného 
řízení zkoumal, jak soud informace včetně osobních údajů poskytoval, a jaký byl jeho důvod pro poskytnutí těchto osobních údajů i přes možnost identifikace konkrétní osoby.

I veřejně dostupné informace mohou být $\mathrm{v}$ případě jejich propojení být zásahem do práva na soukromí, minimálně lze o tomto porušení diskutovat. Příkladem může být např. web $\mathrm{O}$ spravedlnosti ${ }^{36}$ který pracuje $\mathrm{s}$ veřejně přístupnými daty - jeho provozovatelé pracují s daty $\mathrm{v}$ databázi soudních rozhodnutí Ústavního soudu, Nejvyššího soudu a Nejvyššího správního soudu, přičemž tato data analyzují a propojují s informacemi o jednotlivých advokátech, aby pak poskytli informaci o tom, jak si jednotliví advokáti stojí v úspěšnosti podávání ústavních stížností, dovolání a kasačních stížností. Na jednu stranu jde o činnost pochopitelnou, nebot kvalitního advokáta nelze na první pohled poznat. Na druhou stranu je však třeba uvést, že pouhá veřejná dostupnost informace ještě automaticky nezakládá právo takovou informaci zpracovávat. I takové zpracování musí být založeno na existenci právního titulu, a toto zpracování musí být v souladu s účelem, $s$ jakým byla tato data zveřejněna. ${ }^{37}$

V tomto článku jsme se až do této chvíle klonili na stranu spíše extenzivního zveřejňování soudních rozhodnutí - otevřeně přiznáváme, že za nejlepší cestu považujeme úplné zveřejnění celé databáze všech soudních rozhodnutí, a to včetně rozhodnutí všech okresních a krajských soudů

36 Dostupné na adrese: https://oadvokatech.ospravedlnosti.cz/

37 Podnětné jsou v tomto smyslu úvahy v článku NONNEMANN, František. Zpracování veřejně dostupných osobních údajů a GDPR. Právní rozhledy, č. 5, 2018, 167-170. Jako další obdobný př́ípad ze zahraničního prostředí lze uvést rozsudek ESLP ze dne 27. června 2017 ve věci Satakunnan Markkinapörssi Oy a Satamedia Oy proti Finsku, č. 931/13. Ten se týkal toho, že docházelo ke shromažd’ování dat od Finského národního úřadu pro daně za účelem zveřejňování informací o zdanitelných příjmech a majetku fyzických osob. Takové jednání bylo národními orgány pro ochranu osobních údajů zakázáno. Provozovatelé databáze tvrdili porušení práva na svobodu projevu. ESLP se zabýval nalezením rovnováhy mezi právem na př́stup $\mathrm{k}$ datům o plnění daní a právem na soukromí. ESLP konstatoval, že veřejná dostupnost informace ještě neznamená, že pozbývá ochrany poskytované článkem 8 Úmluvy. Ochrana osobních dat má základní význam pro užívání práva na respektování soukromého a rodinného života a národní právo musí poskytovat odpovídající záruky k zabránění jakéhokoliv užití osobních dat, jež může být neslučitelné s garancemi citovaného článku. ESLP tedy závěrem stížnost provozovatelů databáze odmítl. 
podobně, jako tato databáze existuje na Slovensku či v Rakousku. ${ }^{38} \mathrm{Je}$ ovšem rozdíl, jak s těmito údaji jednotlivé subjekty pracují. Pokud jsou tato rozhodnutí používána k seznámení se s rozhodovací praxí soudu, je takový postup v souladu s účelem, pro který byla data použita. Pokud však soukromé subjekty začnou data analyzovat a vytvářet seznamy dlužníků, pachatelů trestných činů či obdobné databáze, jedná se o další zpracování osobních údajů na základě veřejně přístupných dat, které již legitimní v zásadě není, nesvědčí-li takovému zpracování zvláštní důvody.

Akademické zkoumání úspěšnosti advokátů $\mathrm{v}$ řízeních u nejvyšších soudních instancí České republiky je podle nás samo o sobě v pořádku. Naopak může přinést velmi zajímavé informace, podněcující legislativní úpravy procesních předpisů u těchto soudů. Na druhou stranu nepovažujeme za správné zveřejnění těchto údajů s možností identifikovat jednotlivé soukromé osoby, a dokonce mezi nimi provádět vyhledávání, podobně jako bychom nesouhlasili s tvorbou jakékoliv jiné databáze soukromých osob, at už ohledně jejich dluhů, trestní minulosti či jiných podobných údajů.

\subsection{VEŘEJNÝ ZÁJEM ČI SOUKROMÝ ZÁJEM ŽADATELE}

Další kritérium, které by soudy měly jednoznačně zkoumat, je to, zda existuje veřejný či soukromý zájem na zveřejnění informace. Soukromý zájem bude často odpovídat pohnutce žadatele. Představme si situaci, kdy žadatel žádá o informaci z důvodu jiného svého probíhajícího řízení. Danou situaci si dovolíme přirovnat $\mathrm{k}$ naléhavému právnímu zájmu, který je základní podmínkou pro úspěšnost určovací žaloby dle § 80 zákona č. 99/1963 Sb.,

${ }^{38} \mathrm{~V}$ době práce na tomto článku se $\mathrm{v}$ médiích objevila informace, že se spuštění takové databáze připravuje, a že by údajně měla být spuštěná ještě v roce 2019, i když patrně ještě ne se všemi rozsudky. ŠTEFAN, Václav. Online rozsudek. Ministerstvo zavede databázi soudních rozhodnutí, na Slovensku funguje už šest let. iROZHLAS.cz. Publikováno dne: 23.1.2019. Citováno dne 23.1.2019. Dostupné online: http://irozhl.as/4H7. Otázka anonymizace je ale stále relevantní, protože pouhé zveřejnění rozsudků nevyřeší obdobné problémy spojené např̀ se správními rozhodnutími. Dále je také ponechána aktuálnost otázky vědeckého výzkumu, pro jehož účely jsou v některých případech nezbytné demografické údaje, právě jako pro dizertační výzkum, z důvodu kterého provádíme sběr dat my. $\mathrm{V}$ předmětné databázi má fungovat automatický anonymizátor, který odstraní úplně všechny osobní údaje. Relevance zde rozebíraného tématu zůstává zachována i s ohledem na to, že se pravděpodobně ještě rozhoří diskuze o tom, do jaké míry mají být osobní údaje ve všech rozsudcích v této databázi anonymizovány. 
občanský soudní řád. Je možné si představit svědka, kterého potřebuje žadatel identifikovat pro účely soudního řízení, jehož je účastníkem, přičemž nemá jinou možnost, jak toto učinit, než skrze informace o řízení, jehož ovšem není aktivně ani pasivně legitimovaným účastníkem.

Na jednu stranu je možné namítnout, že v takovém případě má žadatel $\mathrm{v}$ rámci jeho se týkajícího soudního řízení označit soudu důkazy, přičemž předmětný spis by si měl vyžádat soud. Na druhou stranu je třeba vzít $\mathrm{v}$ potaz, že informace o tom, jestli se podaří svědky identifikovat či nikoliv, může být klíčovým prvkem pro rozhodnutí, zda soudní řízení vůbec zahajovat. Není nutné připomínat, že nedostatek důkazů pochopitelně vede $\mathrm{k}$ neúspěchu ve sporu. Často proto může $\mathrm{k}$ dotazu na obsah rozhodnutí dojít ještě před zahájením soudního řízení týkajícího se žadatele.

Veřejný zájem je snad ještě jednoznačnější kritérium. Veřejný zájem se vztahuje $\mathrm{k}$ věcem, které ovlivňují veřejnost do takové míry, že se o ně může zajímat, které přitahují její pozornost nebo které se jí týkají do značného stupně, zvláště pokud ovlivňují životní úroveň občanů nebo život společnosti. Veřejný zájem nemůže být redukován na žízeň veřejnosti po informacích o soukromém životě jiných, nebo na touhu publika po honbě za senzacemi nebo dokonce voyeurismu. ${ }^{39}$ Pokud je znalost určitých informací veřejným zájmem, je logické, že tento veřejný zájem může převážit nad právem na soukromí osoby, které se uvedené informace týkají.

V trestních rozsudcích mohou být rozhodujícím kritériem totožnost pachatele a povaha činu. Informace, o jakého pachatele se jedná, může odůvodnit důležitost jeho identifikace. Větší zájem na identifikaci pachatele lze spatřovat $\mathrm{u}$ veřejně činných osob, např. politiků. ${ }^{40} \mathrm{Z}$ hlediska dohledu veřejnosti na výkon státní moci musí být zejména u veřejně činných osob

${ }^{39}$ Nález Ústavního soudu ze dne 17. října 2017, sp. zn. IV. ÚS 1378/16, § 88.

${ }^{40}$ K otázce nižší ochrany soukromí u politiků a osob zastávajících politické funkci či státní úřady existuje rozsáhlá judikatura Ústavního soudu i Evropského soudu pro lidská práva. Pokud jde o otázky veřejného zájmu, bude projev požívat vyšší ochrany. Srov. KMEC, Jiří. KOSAŘ, David. KRATOCHVÍL, Jan. BOBEK, Michal. Evropská úmluva o lidských právech. Komentár. Praha: C.H. Beck, 2012, s. 911-913. 
patrné, že se dopouštěly trestné činnosti, která mohla s výkonem jejich mandátu souviset. ${ }^{41}$

O jaký čin se jedná, je taktéž relevantní, nebot u některých trestných činů je $s$ informací o jejich spáchání spojený vyšší veřejný zájem než u jiných. Lze zejména zdůraznit rozdíl mezi nedbalostními a úmyslnými trestnými činy. Níže se text bude věnovat účelu trestu a tomu, že účelem trestu je veřejné odsouzení činu pachatele. ${ }^{42} \mathrm{~V}$ podstatě u každého trestného činu tak existuje určitý veřejný zájem na tom, aby se o jeho spáchání veřejnost dozvěděla. Tento veřejný zájem je však u některých trestných činů nižší a u některých vyšší. Problém $s$ informacemi o trestní minulosti je zejména ten, že se často jedná o „cejch”, který si s sebou dotyčná osoba nese kvůli skutkům spáchaným $\mathrm{v}$ minulosti, přestože objektivně došlo $\mathrm{k}$ její nápravě. Po vykonání trestu jsou často pachatelé stigmatizováni, a mohou tak mít problém s hledáním zaměstnání či ubytování. Zejména u nedbalostních trestných činů je taková stigmatizace zcela zbytečná a nežádoucí.

Některé druhy trestné činnosti jsou provázeny značným veřejným zájmem na vědomosti o nich. Jedná se o závažnou hospodářskou trestnou činnost, trestné činy proti životnímu prostředí, podvodná jednání apod.

Opět se vracíme $\mathrm{k}$ myšlence, kterou jsme vyslovili v minulé kapitole důležité je individuální posuzování, nikoliv činění paušálních závěrů. Kritérií, která lze zohlednit, je mnoho - jak je vidět na této kapitole. Domníváme se, že jejich nezohlednění nutně vede $\mathrm{k}$ závěru o porušení práva na

${ }^{41}$ Ve vztahu ke zveřejňování fotografií lze zmínit rozsudek Evropského soudu pro lidské práva ve věci News Verlags GmbH \& Co.KG proti Rakousku byly v časopise zveřejněny fotografie pravicového extremisty, který byl podezřelý ze zaslání dopisů $s$ výbušninami několika veřejně činným osobám. Soud uvedl, že případné porušení soukromí podezřelého bude záležet na okolnostech daného př́padu a zejména podstatě trestného činu. Pokud jde o trestný čin s politickým kontextem a navíc podezřelá osoba již dříve nebyla čistě soukromou osobou, bude zákaz zveřejnění fotografie podezřelého představovat nepřiměřený zásah do svobody projevu. [rozsudek, 11. 1. 2000, č. 31457/96, § 58] A contrario je tedy možné dovodit, že se nebude jednat o neústavní zásah do práva na soukromí.

${ }^{42}$ Tím se liší ochranná opatření od trestů, uložení ochranného opatření nevyjadřuje negativní hodnocení osoby pachatele, zatímco uložení trestu ano. Srov. JELÍNEK, Jiří a kol. Trestní právo hmotné. 3. vydání. Praha: Leges, 2013, s. 456. Trest se dá definovat jako opatření státního donucení, kterým se vyslovuje společenské odsouzení činu a jeho pachatele. NOVOTNÝ, Oto a kol. Trestní právo hmotné. Obecná část. 3. vydání, Praha: Codex, 1997, str. 197. 
informace žadatele. To neznamená, že žadateli musí být vždy vyhověno - je však naprosto nutné, aby se těmito kritérii soud či jakýkoliv jiný povinný subjekt zabýval, nebot' $\mathrm{v}$ opačném případě bude jeho rozhodnutí nepřezkoumatelné a mělo by být odvolacím orgánem, potažmo správním soudem, zrušeno.

\section{KOLIZE NEPOSKYTNUTÍ INFORMACÍ O ODSOUZENÍ $S$ ÚČELEM TRESTU}

V předchozí kapitole již bylo naznačeno, že informace o trestní minulosti pachatele mají specifický charakter hned v několika aspektech. Na jednu stranu je jedním z účelů trestního práva veřejné odsouzení činu pachatele. ${ }^{43}$ Na druhou stranu však Obecné nařízení ve svém čl. 9 vymezuje tzv. zvláštní kategorie osobních údajů a upravuje také přípustné způsoby s jejich nakládáním. K tomuto ustanovení je třeba přidat ustanovení čl. 10, to totiž vedle zvláštních kategorií osobních údajů vymezuje ještě osobní údaje týkající se rozsudků v trestních věcech a trestných činů. ${ }^{44}$

43 JELÍNEK, Jiří a kol. Trestní právo hmotné. 3. vydání. Praha: Leges, 2013, s. 386.

44 Zdá se, že Nařízení je formulováno takovým způsobem, že tyto osobní údaje týkající se trestního odsouzení nejsou čl. 10 zařazeny mezi zvláštní kategorie osobních údajů, ale že se jedná ještě o další samostatnou kategorii, na kterou se patrně budou vztahovat obdobně pravidla jako pro zvláštní kategorie osobních údajů. To, že Nařízení pracuje s těmito koncepty jako s odlišnými pojmy je patrné např. z dikce čl. 6 odst. 4 písm. c) Nařízení. Stejné rozdělení naznačuje také odst. 91 důvodové zprávy k tomuto Nařízení. Stejného názoru je i NULÍČEK, Michal a kol. GDPR. Obecné nařizzení o ochraně osobních údajů. Praktický komentár̆. Praha: Wolters Kluwer ČR, 2017, s. 169, podle kterého: „Na rozdíl od zákona o ochraně osobních údajů Nařizení neoznačuje osobní údaje týkající se rozsudků v trestních věcech a trestných činů za součást citlivých údajů. Namísto toho pro ně stanoví speciální kategorii a definuje pro jejich zpracování odlišné podmínky."

Problémem ovšem je, že čl. 10 ovšem sám o sobě není dostatečně konkrétní a je otázkou, jestli se má analogicky aplikovat čl. 9 odst. 2, pokud jde o způsob nakládání s osobními údaji. Čl. 10 totiž vymezuje pouze to, že zpracování může provádět pouze pod dozorem orgánu veřejné moci nebo $\mathrm{v}$ případě, že je to oprávněné podle práva Unie nebo členského státu. Jde zejména o vyřešení otázky, zda se aplikuje na informace o trestním odsouzení čl. 9 odst. 2 písm. g), tedy titul pro zpracování v případě významného veřejného zájmu přiměřeného sledovanému cíli a poskytujícími vhodné a konkrétní záruky pro ochranu práv a zájmů subjektu údajů, a také čl. 9 odst. 2 písm. j), pokud je zpracování nezbytné pro účely archivace ve veřejném zájmu, pro účely vědeckého nebo historického výzkumu či pro statistické účely. 
To znamená, že na jednu stranu je vlastně záměrem, aby se veřejnost dozvěděla o spáchání trestného činu konkrétní osobou, o potrestání této osoby a o vyslovení společenské nepřípustnosti tohoto činu. Jedná se de facto o naplnění jedné z funkcí trestního práva, totiž funkci generální prevence trestné činnosti. ${ }^{45} \mathrm{Na}$ druhou stranu však existuje potřeba osobu pachatele chránit, a to právě s ohledem na možnou stigmatizaci ve všech oblastech života, zejména $\mathrm{v}$ souvislosti se zaměstnáváním. $\mathrm{V}$ tomto ohledu lze zmínit, že § 316 odst. 4 písm. h) zákona č. 262/2006 Sb., zákoníku práce, zakotvuje, že zaměstnavatel nesmí vyžadovat od zaměstnance informace, které bezprostředně nesouvisejí s výkonem práce, přičemž v uvedeném demonstrativním výčtu je výslovně uvedena i trestněprávní bezúhonnost. Výjimkou, kdy může zaměstnavatel tyto informace získávat, je věcný důvod spočívající v povaze práce, která má být vykonávána, za předpokladu, že je tento požadavek přiměřený, nebo $v$ případech, kdy to stanoví zákon či jiný právní předpis.

Jedná se o ustanovení, které je v praxi poměrně rozsáhlým způsobem porušováno, nebot existuje stále značné množství zaměstnavatelů, kteří po potenciálních zaměstnancích požadují výpis z trestní rejstříku zcela automaticky, aniž by byl takový požadavek objektivně odůvodněn. Toto ustanovení lze však uvést jako další příklad ochrany osob s trestněprávní minulostí.

Nacházíme se tak opět u vyvažování dvou protichůdných zájmů. Stejně jako v předcházející kapitole je třeba zdůraznit roli proporcionality. Lze si představit extrémní případy, ve kterých bude naše stanovisko o tom, jestli má být taková informace dostupná či nikoliv, poměrně jednoznačné. Dále však existuje množství případů nacházejících se v šedé oblasti.

Pokud jde o rozsáhlé zpracování údajů o trestných činech, pak je nepochybné, že bude nutné provést posouzení vlivu na ochranu osobních údajů a patrně i povinnost jmenovat pověřence pro ochranu osobních údajů dle čl. 37 Nařízení. Srov. NULíčEK, Michal a kol. GDPR. Obecné nařízení o ochraně osobních údajů. Praktický komentář. Praha: Wolters Kluwer ČR, 2017, s. 170-171. Rozsáhlejší výklad o přesné povaze povinností při nakládání s těmito údaji ovšem přenecháváme jiným akademikům. Pro naší další analýzu je totiž podstatné pouze to, že informace o trestním odsouzení požívají oproti obecné úpravě ochrany osobních údajů ještě zvláštní ochrany.

45 JELÍNEK, Jiří a kol. Trestní právo hmotné. 3. vydání. Praha: Leges, 2013, s. 25. 
Stejně jako v předcházející kapitole je třeba zdůraznit, jak problematická je situace, kdy soud bez jakékoliv úvahy učiní dogmatický závěr o neposkytnutí informací či informace. Stejně jako v případě kolize mezi právem na soukromí a právem na informace existuje řada okolností ovlivňujících závěr o existenci veřejného zájmu odůvodňující poskytnutí informací veřejnosti a dostatečné závažnosti veřejného zájmu, aby tak mohlo dojít k legitimizaci zásahu do práva na soukromí pachatele trestného činu.

Silný názor pro zveřejňování informací je založený na tom, že pachatel se svého práva na soukromí vzdává již samotným spácháním trestného činu. Rozhodnutí o protiprávní činnosti učinil samotný pachatel s jednoznačným vědomím toho, že $\mathrm{v}$ případě dopadení bude trestně stíhán, odsouzen a veřejnost bude mít pochopitelně možnost se o této informaci dozvědět.

Takto silné stanovisko pochopitelně zaujmout nechceme, rozhodně nejsme nakloněni veřejnému lynčování pachatelů za jejich trestnou činnost, a to právě s ohledem na možnou stigmatizaci i poté, co pachatelé podstoupili svůj trest. Zároveň ovšem chceme poukázat na problematičnost závěrů, které vyplývají z omezování př́stupu $\mathrm{k}$ informacím o trestním odsouzení. Odsouzení v trestních věcech má obecně výchovnou úlohu vůči společnosti, tedy tzv. negativně-výchovný efekt, ${ }^{46}$ posiluje vnímání autority práva a přesvědčení, že jednání naplňující skutkovou podstatu trestního zákoníku bude také potrestáno a bude uložen trest.

Jedno z možných řešení je rozlišit mezi okamžiky, kdy má dojít k přístupu k informacím. Je rozdíl mezi vznikem soukromé databáze svým obsahem odpovídající rejstř́ku trestů vzniklé indexací zveřejněných rozhodnutí, podle kterých by se dal identifikovat konkrétní pachatel (takto funguje např. databáze Sex Offenders v USA ${ }^{47}$, a informacemi o odsouzení v okamžiku odsouzení a do ukončení výkonu trestu, např. nepodmíněného odnětí svobody. Nejsou-li totiž tyto informace dostupné, není tím naplňován jeden z účelů trestu - již zmíněné veřejné odsouzení činu pachatele.

46 ŠÁMAL, Pavel a kol. Trestní právo hmotné. 8. vydání. Praha: Wolters Kluwer, 2016, s. 37. 


\section{OTÁZKA VEŘEJNOSTI SOUDNÍHO ŘÍZENÍ A DOHLEDU NAD JUSTICÍ}

Existuje ještě jeden aspekt, který je vhodné zmínit. Zásada veřejnosti v soudním řízení je prvkem práva na spravedlivý proces, čímž požívá ústavněprávní relevance. Jedná se o jedno z nejsilnějších opatření, které má předcházet fungování a vzniku tzv. kabinetní justice, ${ }^{48}$ má zvyšovat transparentnost soudního rozhodnutí a zvyšovat důvěru obyvatel v soudy a v nezaujatost jejich rozhodování. ${ }^{49} \mathrm{~V}$ českých zemích byla kontrola tradičně chápána jako jediný a hlavní význam zásady veřejného soudního

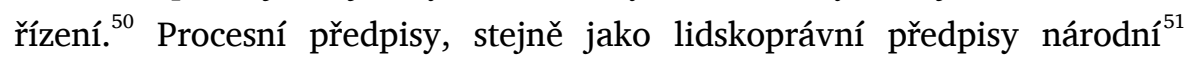
i mezinárodní úrovně ${ }^{52}$, $\mathrm{z}$ ní samozřejmě pro určité druhy řízení (např. trestní řízení s mladistvými) či pro určité př́ípady (např̀. z důvodu mravnosti, národní bezpečnosti či soukromého života účastníků) činí vý-

${ }^{47}$ Srov. DIECIDUE, Emmaleigh. The Problem with the National Sex Offender Registry. The Odyssey Online. Publikováno dne: 15. 8. 2016. Citováno dne: 30. 10. 2018. Dostupné online: https://www.theodysseyonline.com/problem-national-sex-offenders-registry. Je ale vhodné zmínit, že př́klady jako tyto nejsou řešeny pouze v angloamerickém prostředí, ale velmi podobný př́ípad byl řešen i Evropským soudem pro lidská práva, přičemž zásah do práva na soukromí byl shledán za v souladu s Úmluvou. $V$ rámci rozsudku ESLP ze dne 17. prosince 2009 ve věci Bouchacourt proti Francii se řešila otázka, jestli př́ípad zapsání do národního automatizovaného registru $\mathrm{v}$ př́padě odsouzení za znásilnění a sexuální násilí na dítěti je v souladu s právem na soukromí. Proporcionalita vzhledem k legitimnímu cíli veřejné bezpečnosti a předcházení zločinnosti byla dle ESLP zachována.

48 ŠIMÍČEK, Vojtěch. In: BAHÝL’OVÁ, Lenka a kol. Komentár. Ústava České republiky. Praha: Linde, 2010, s. 1309.

49 Rozsudek Nejvyššího správního soudu ze dne 16. srpna 2017, sp. zn. 4 As 46/2016-94.

${ }^{50}$ Nález Ústavního soudu ze dne 8. listopadu 2005, sp. zn. Pl. ÚS 28/04.

${ }^{51}$ Čl. 38 odst. 2 Listiny základních práv a svobod (dále jen „Listina“) stanovuje: „Každý má právo, aby jeho věc byla projednána veřejně, bez zbytečných průtahů a $v$ jeho př́tomnosti a aby se mohl vyjádřit ke všem prováděným důkazům. Veřejnost může být vyloučena jen $v$ př́padech stanovených zákonem."

52 Čl. 6 odst. 1 Úmluvy o ochraně lidských práv a základních svobod (dále jen „Úmluva“) stanovuje: „Každý má právo na to, aby jeho záležitost byla spravedlivě, veřejně a v přiměřené lhůtě projednána nezávislým a nestranným soudem zř̌zeným zákonem, který rozhodne o jeho občanských právech nebo závazcích nebo o oprávněnosti jakéhokoli trestního obvinění proti němu. Rozsudek musí být vyhlášen veřejně, avšak tisk a veřejnost mohou být vyloučeny bud' po dobu celého nebo části procesu $v$ zájmu mravnosti, veřejného pořádku nebo národní bezpečnosti $v$ demokratické společnosti, nebo když to vyžaduji zájmy nezletilých nebo ochrana soukromého života účastníků, anebo $v$ rozsahu považovaném soudem za zcela nezbytný pokud by, vzhledem ke zvláštním okolnostem, veřejnost ř́zení mohla být na újmu zájmům spravedlnosti.“ 
jimky. ${ }^{53}$ I když je veřejnost z řízení vyloučena, rozsudek musí být vždy vyhlášen veřejně ${ }^{54}$ což je požadavek zakotvený právě čl. 6 Úmluvy a podle doktríny minimálního jmenovatele lidskoprávní ochrany se tento standard musí uplatnit, i když s ním Listina takto neoperuje.

Jeden z účelů, který v naší argumentaci zatím nebyl zmíněn, je otázka řádného a transparentního fungování soudní moci. Veřejné soudní řízení je garancí nestrannosti, nezávislosti soudů a jejich zákonného procesního postupu. Významnou rovinou zásady je dále možnost naplnit prostřednictvím prrímé účasti na soudním řízení právo na informace o činnosti státních (soudních) orgánů. ${ }^{55}$ Každé soudní řízení je s ohledem na jeho veřejnost nepochybně zásahem do soukromí. Právě proto je fakt „praní špinavého prádla na veřejnosti“ jak pro jednotlivce, tak pro obchodní společnosti často jedním $\mathrm{z}$ důvodů, proč se pokusit spory řešit alternativní cestou - mediací či neveřejnou arbitráží.

Na jednu stranu je třeba představit názor, že dohled nad fungováním justice a záruky její nestrannosti a nezávislosti jsou dány již veřejností soudního jednání samotného. $S$ veřejným vynesením rozsudku již je podle některých názorů veřejnosti dokázáno, že $\mathrm{v}$ řízení proběhlo vše $\mathrm{v}$ pořádku a je poté pouze na jednotlivcích, jestli svého práva na kontrolu justice využijí či nikoliv.

Přesto si dovolíme tvrdit, že situace je složitější. Je možné citovat nález Ústavního soudu, s jehož závěry a argumentací se plně ztotožňujeme, a podle kterého s ohledem na podstatu a význam zásady veřejnosti soudního řízení se nelze při její aplikaci omezit pouze na umožnění př́stupu veřejnosti do soudní síně $\mathrm{v}$ době jednání. ${ }^{56}$ Ústavní soud dále

${ }^{53}$ Zejména k posledním bodu, který výslovně zakotvuje čl. 6 odst. 1 Úmluvy, je třeba se vyjádřit tak, že zde musí být skutečně legitimní důvod pro omezení účasti veřejnosti, to stejné se vztahuje i na omezení veřejnosti při vyhlášení rozhodnutí. Omezení veřejnosti musí být v každém případě nezbytné, srov. KMEC, Jiří. KOSAŘ, David. KRATOCHVÍL, Jan. BOBEK, Michal. Evropská úmluva o lidských právech. Komentárr. Praha: C.H. Beck, 2012, s. 688.

${ }^{54}$ ŠIMÍČEK, Vojtěch. In: BAHÝL'OVÁ, Lenka a kol. Komentář. Ústava České republiky. Praha: Linde, 2010, s. 1310.

${ }^{55}$ KŘ́̌́̌̌KOVÁ, Michaela. Publikace rozhodnutí státních orgánů a ochrana osobních údajů. Diplomová práce. Právnická fakulta Masarykovy univerzity, 2006, s. 11.

56 Nález Ústavního soudu ze dne 14. února 2008, sp. zn. II. ÚS 2672/07. 
uvádí: „Tato forma je nepochybně pưvodní a základní, avšak stejně jako jiné oblasti života a nauky i právní řád prošel vývojem, který nutně musel reflektovat nové možnosti mezilidských vztahů, vytvářených zejména rozvíjejicími se službami a technickým pokrokem. Ten reprezentuje především nástup vlivu a významu masových sdělovacích prostředků, resp. technických prostředků, které tato média při své činnosti využivají. “57 Vylučování některé formy veřejnosti musí být podle Ústavního soudu vždy propojeno s legitimním cílem, $\mathrm{v}$ opačném případě se jedná o svévolí míjící se $\mathrm{s}$ cílem principu veřejnosti soudního řízení. Podle Ústavního soudu však nelze princip veřejnosti pojímat jako princip stanovený pouze ve prospěch osob odlišných od účastníků řízení, nýbrž je třeba jej chápat i jako princip umožňující právo na svobodu projevu v souvislosti s kritikou konkrétního fungování soudní moci. Účastníci soudního řízení spadají do množiny veřejnosti a v tomto ohledu je jejich postavení vůči soudu identické. ${ }^{58}$

Ústavní soud se $\mathrm{v}$ tomto nálezu zabýval otázkou pořizování zvukového záznamu ze soudního jednání, kdy konkrétně vykládal ustanovení § 6 odst. 3 zákona č. 6/2002 Sb., o soudech a soudcích. Ústavní soud uzavřel, že podle tohoto ustanovení soud nemůže zakázat pořizování zvukového zázna$\mathrm{mu}$, protože zvukový záznam se pořizuje pouze s vědomím soudu, nikoliv s jeho povolením (čímž se zvukový záznam liší od záznamu zvukově obrazového). $\mathrm{Z}$ toho důvodu předmětné rozhodnutí zrušil, nebot nepřivolením k pořízení zvukového záznamu z ústního jednání porušil obecný soud čl. 96 odst. 2 Ústavy a tím také základní právo podle čl. 2 odst. 3 a čl. 38 odst. 2 Listiny

Tím nepochybně vzniká otázka - pokud se během soudního řízení a během vyhlašování rozsudku, které je vždy veřejné, všechny osoby otevřeně oslovují jmény a veřejnost se může seznámit i s jinými osobními údaji, přičemž kdokoliv z veřejnosti si může cokoliv, co se na soudním jednání děje, nahrávat i přes nesouhlas soudu (resp. nesouhlas soudu není relevantní, postačuje jeho vědomost o tom, že dochází k nahrávání), je zde opravdu legitimní cíl na tom, aby tyto údaje nebyly dostupné i v písemném vyhotovení

\footnotetext{
57 Tamtéž, § 12.

58 Tamtéž, § 13-14.
} 
rozhodnutí, které je veřejnosti podle zákona o svobodném přístupu $\mathrm{k}$ informacím taktéž dostupné? $\mathrm{V}$ této oblasti ostatně nejsme $\mathrm{z}$ odborné veřejnosti prvními, kdo toto odstraňování údajů, které již byly $\mathrm{v}$ rámci soudního řízení jednou zveřejněny, kritizuje. ${ }^{59}$

\section{ZÁVĚR}

Hlavním závěrem našeho článku je, že $v$ případě anonymizace osobních údajů v soudních rozhodnutích vyžádaných na základě práva na informace se jedná o konflikt dvou základních práv (práva na soukromí a práva na informace) a několika veřejných zájmů. Zaprvé je to veřejnost řízení, jež je instrumentální hodnotou pro veřejnou kontrolu justice a zárukou pro její nezávislost, nestrannost a pro důvěru $\mathrm{v}$ ní. $\mathrm{V}$ případě trestního řízení se jedná o naplnění vůbec základního účelu trestu - toho, že trestním odsouzením má dojít $\mathrm{k}$ veřejnému odsouzení činu pachatele a konstatování jeho závažnosti.

Domníváme se, že aplikační praxí př̀i poskytování informací o rozhodovací činnosti soudů i na základě poměrně restriktivního znění Instrukce Ministerstva spravedlnosti, která jakožto interní normativní akt sjednocuje poskytování informací soudy, dochází k porušování principů, na kterých je založen zákon o svobodném přistupu $\mathrm{k}$ informacím a ochrana lidských práv. Soudy jako povinné subjekty často činí dogmatické závěry o tom, že některé druhy informací je třeba bezvýhradně anonymizovat, aniž by $\mathrm{z}$ jejich strany docházelo $\mathrm{k}$ poměřování lidských práv jako legitimního prostředku pro řešení konfliktu mezi více ústavněprávními hodnotami.

59 Viz DERKA, Ladislav. KÜHN, Zdeněk. Je anonymizace publikovaných soudních rozhodnutí vskutku nutná?. Jurisprudence. Roč. 15, č. 1, 2005, s. 21-25, či KÜHN, Zdeněk. BAŇOUCH, Hynek. O publikaci a citaci judikatury aneb proč je někdy judikatura jako císařovy nové šaty. Právní rozhledy. Roč. 13, č. 13, 2005, s. 484-491. V krátkosti jsou zde představené obdobné argumenty - zahájením soudního řízení se vstupuje na veřejné fórum, přičemž v tom případě musejí strany strpět, že pokud se jedná o zajímavý spor, že se může veřejnost dostavit. S ohledem na to, že jsou údaje o účastnících dostupné i na úřední desce soudu a u dveří jednací síně, nedává smysl údaje anonymizovat posléze v rozsudku. 
V tomto článku byla představena kritéria, která by měly povinné subjekty zvážit, pokud se v rámci informací požadovaných z titulu práva na informace vyskytují i informace zasahující do práva na soukromí osob, kterých se vyžádané dokumenty týkají. Zaprvé jde o kritérium, zda je na základě těchto informací osoba vůbec identifikovatelná, či zda jde stále o tak obecné údaje, že k zásahu do práva na soukromí vůbec nedojde. Zadruhé je to pohnutka a motivace žadatele o informaci, což je sice kritérium, jehož zkoumání je na základě zákona o svobodném přístupu k informacím a judikatuře $\mathrm{k}$ němu obecně vyloučeno, $\mathrm{v}$ daném případě se však zkoumání pohnutky nevztahuje k samotnému poskytnutí informace, nýbrž pouze k míře anonymizace osobních údajů v ní obsažených. Zatřetí jde pak o kritérium toho, zda existuje identifikovatelný právní zájem žadatele na této informaci, či zda existuje zájem veřejný. Jak $\mathrm{v}$ případě soukromého, tak $\mathrm{v}$ prrípadě veřejného zájmu je třeba tento zájem poměřovat s právem na soukromí a vyvažovat, kterému z těchto zájmů dát přednost.

Nečiníme si za cíl učinit výčet kritérií vyčerpávajícím způsobem a nevylučujeme možnost, že existují další kritéria, jejichž zohlednění by ještě více optimalizovalo rozhodování o kolizi těchto dvou lidských práv. Dle našeho názoru však uplatnění $\mathrm{i}$ jenom těchto kritérií povede $\mathrm{v}$ aplikační praxi ke zvýšení respektu k oběma lidským právům, právu na soukromí i právu na informace, nebở začnou být považovány za dvě rovnocenné ústavněprávní hodnoty.

\section{SEZNAM LITERATURY}

\subsection{ODBORNÉ TEXTY}

[1] ČERVÍNEK, Zdeněk. Standardy přezkumu ústavnosti v judikatuře Ústavního soudu. Jurisprudence, č. 4, 2015, s. 21-29.

[2] DERKA, Ladislav. KÜHN, Zdeněk. Je anonymizace publikovaných soudních rozhodnutí vskutku nutná?. Jurisprudence. Roč. 15, č. 1, 2005, s. 21-25.

[3] FUREK, Adam. ROTHANZL, Lukáš. JIROVEC, Tomáš. Zákon o svobodném př́stupu k informacím. Komentár. Praha: C.H. Beck, 2016, 1238 s.

[4] GERLOCH, Aleš. Teorie práva. 6. vydání. Plzeň: Aleš Čeněk, 2013, 310 s. 
[5] GRUODYTÉ, Edita. MILČIUVIENÉ, Saulé. Anonymization of Court Decisions: Are Restrictions on the Right to Information in "Accordance with the Law"?. Baltic Journal of Law \& Politics. Roč. 9, č. 2, 2016, s. 150-170.

[6] JELÍNEK, Jiří a kol. Trestní právo hmotné. 3. vydání. Praha: Leges, 2013, 986 s.

[7] JELÍNKOVÁ, Jitka. TUHÁČEK, Miloš. Zákon o svobodném př̌stupu k informacím. Praktický komentár. Praha: Wolters Kluwer, 2017, 284 s.

[8] KMEC, Jiří. KOSAŘ, David. KRATOCHVÍL, Jan. BOBEK, Michal. Evropská úmluva o lidských právech. Komentár̆. Praha: C.H. Beck, 2012, 1696 s.

[9] KOLMAN, Jiří. Právo na informace jako základní lidské právo. Právní prostor. Publikováno 7.1.2016, citováno dne 23.1.2016. Dostupné online: https://www.pravniprostor.cz/clanky/ustavni-pravo/pravo-na-informace-jako-zakladni-lidskepravo

[10] KOSAŘ, David. Kolize základních práv v judikatuře Ústavního soudu ČR. Jurisprudence, č. 1, 2008, s. 3-19.

[11] KŘÍŽKOVÁ, Michaela. Publikace rozhodnutí státních orgánů a ochrana osobních údajů. Diplomová práce. Právnická fakulta Masarykovy univerzity, 2006, $101 \mathrm{~s}$.

[12] KÜHN, Zdeněk. Aplikace práva ve složitých př́padech - $k$ úloze právních principů v judikatuře. Praha: Nakladatelství Karolinum, 2002, 419 s.

[13] KÜHN, Zdeněk. BAŇOUCH, Hynek. O publikaci a citaci judikatury aneb proč je někdy judikatura jako císařovy nové šaty. Právní rozhledy. Roč. 13, č. 13, 2005, s. 484-491.

[14] NULíČEK, Michal a kol. GDPR. Obecné nař́zení o ochraně osobních údajů. Praktický komentár̆. Praha: Wolters Kluwer ČR, 2017, 580 s.

[15] NONNEMANN, František. Zpracování veřejně dostupných osobních údajů a GDPR. Právní rozhledy, č. 5, 2018, 167-170.

[16] NOVOTNÝ, Oto a kol. Trestní právo hmotné. Obecná část. 3. vydání, Praha: Codex, 1997, $328 \mathrm{~s}$.

[17] ŠÁMAL, Pavel a kol. Trestní právo hmotné. 8. vydání. Praha: Wolters Kluwer, 2016, 1052 s.

[18] ŠIMÍČEK, Vojtěch. In: BAHÝLOVÁ, Lenka a kol. Komentár̆. Ústava České republiky. Praha: Linde, 2010, $1536 \mathrm{~s}$.

[19] WAGNEROVÁ, Eliška a kol. Listina základních práv a svobod Komentář. Praha: Wolters Kluwer, 2012, $931 \mathrm{~s}$.

\subsection{NEODBORNÉ ZDROJE}

[20] BRENKA, Gabriel. Nová úprava anonymizace rozhodnutí Ústavního soudu. brenka.eu. Publikováno dne 18. 9. 2013. Citováno dne 31. 10. 2018. Dostupné online: http://brenka.eu/nova-uprava-anonymizace-rozhodnuti-ustavniho-soudu/ 
[21] DIECIDUE, Emmaleigh. The Problem with the National Sex Offender Registry. The Odyssey Online. Publikováno dne: 15. 8. 2016. Citováno dne: 30. 10. 2018. Dostupné online: https://www.theodysseyonline.com/problem-national-sex-offenders-registry

[22] ŠTEFAN, Václav. Online rozsudek. Ministerstvo zavede databázi soudních rozhodnutí, na Slovensku funguje už šest let. iROZHLAS.cz. Publikováno dne: 23.1.2019. Citováno dne 23.1.2019. Dostupné online: http://irozhl.as/4H7.

[23] Základní příručka k GDPR. Úřad pro ochranu osobních údajů. Citováno dne: 23.1.2019. Dostupné online: https://www.uoou.cz/zakladni-prirucka-k-gdpr/ds$4744 / \operatorname{archiv}=0 \& \mathrm{p} 1=4726$

\subsection{JUDIKATURA}

[24] Nález Ústavního soudu ze dne 13. srpna 2002, sp. zn. Pl. ÚS 3/02.

[25] Nález Ústavního soudu ze dne 14. července 2004, sp. zn. I. ÚS 185/04.

[26] Nález Ústavního soudu ze dne 15. března 2005, sp. zn. I. ÚS 367/03.

[27] Nález Ústavního soudu ze dne 8. listopadu 2005, sp. zn. Pl. ÚS 28/04

[28] Nález Ústavního soudu ze dne 20. června 2006, sp. zn. Pl. ÚS 38/04.

[29] Nález Ústavního soudu ze dne 1. března 2007, sp. zn. Pl. ÚS 8/06.

[30] Nález Ústavního soudu ze dne 17. července 2007, sp. zn. IV. ÚS 23/05.

[31] Nález Ústavního soudu ze dne 14. února 2008, sp. zn. II. ÚS 2672/07.

[32] Nález Ústavního soudu ze dne 12. března 2008, sp. zn. Pl. ÚS 83/06.

[33] Nález Ústavního soudu ze dne 15. listopadu 2010, sp. zn. I. ÚS 517/10.

[34] Nález Ústavního soudu ze dne 19. července 2016, sp. zn. Pl. ÚS 20/15.

[35] Nález Ústavního soudu ze dne 17. října 2017, sp. zn. IV. ÚS 1378/16.

[36] Nález Ústavního soudu ze dne 3. dubna 2018, sp. zn. IV. ÚS 1200/16.

[37] Rozsudek Evropského soudu pro lidská práva ze dne 27. června 2017 ve věci Satakunnan Markkinapörssi Oy a Satamedia Oy proti Finsku, č. 931/13.

[38] Rozsudek Evropského soudu pro lidská práva ze dne 14. dubna 2009 ve věci Társaság a Szabadságjogokért proti Mad’arsku, č. 37374/05.

[39] Rozsudek Evropského soudu pro lidská práva ze dne 26. května 2009 ve věci Kenedi proti Mad'arsku, č. 31475/05.

[40] Rozsudek Evropského soudu pro lidská práva ze dne 17. prosince 2009 ve věci Bouchacourt proti Francii, č. 5335/06.

[41] Rozsudek Nejvy̌ššího správního soudu ze dne 27. června 2007, sp. zn. 6 As 79/2006-58.

[42] Rozsudek Nejvyššího správního soudu ze dne 22. ř́ijna 2014, sp. zn. 8 AS 55/2012-62.

[43] Rozsudek Nejvyššího správního soudu ze dne 16. srpna 2017, sp. zn. 4 As 46/2016-94. 
[44] Rozsudek Soudního dvora EU ze dne 9. listopadu 2010 ve věci Volker und Markus Schecke GbR (C-92/09) a Hartmut Eifert (C-93/09).

[45] Rozsudek Soudního dvora EU ze dne 6. ř́jna 2015 ve věci Schrems (C-362/14).

Toto dílo lze užít v souladu s licenčními podmínkami Creative Commons BY-SA 4.0 International (http://creativecommons.org/licenses/by-sa/4.0/legalcode). 